Board of Governors of the Federal Reserve System

International Finance Discussion Papers

Number 1076

April 2013

\title{
Revenge of the Steamroller: ABCP as a Window on Risk Choices
}

\author{
Carlos Arteta \\ Mark Carey \\ Ricardo Correa \\ Jason Kotter
}

NOTE: International Finance Discussion Papers are preliminary materials circulated to stimulate discussion and critical comment. References to International Finance Discussion Papers (other than an acknowledgment that the writer has had access to unpublished material) should be cleared with the author or authors. Recent IFDPs are available on the Web at www.federalreserve.gov/pubs/ifdp/. This paper can be downloaded without charge from the Social Science Research Network electronic library at www.ssrn.com 


\title{
Revenge of the Steamroller: ABCP as a Window on Risk Choices
}

\author{
Carlos Arteta \\ Federal Reserve Board \\ Mark Carey \\ Federal Reserve Board \\ Ricardo Correa \\ Federal Reserve Board \\ Jason Kotter \\ University of Michigan - Ross School of Business
}

March 2013

\begin{abstract}
We empirically examine financial institutions' motivations to take systematic bad-tail risk in the form of sponsorship of credit-arbitrage asset-backed commercial paper vehicles. A run on debt issued by such vehicles played a key role in causing and propagating the liquidity crisis that began in the summer of 2007. We find evidence consistent with important roles for both ownermanager agency problems and government-induced distortions, especially government control or ownership of banks.
\end{abstract}

Keywords: Risk decisions, systemic risk, bank runs, financial crisis, commercial paper

JEL Classifications: G20, G01, G32, G38

\footnotetext{
* Corresponding author is Mark Carey, mark.carey@frb.gov; Mail Stop 44, Federal Reserve Board, Washington DC, 20551, 202-452-2784. We thank Adam Ashcraft, Norah Barger, Tom Boemio, Sally Davies, Toni Gravelle, Gary Gorton, David Jones, Steve Kamin, George Pennacchi, Nathan Sheets, Philipp Schnabl, Gustavo Suarez and many others for useful conversations and suggestions. The views in this paper are solely the responsibility of the authors and should not be interpreted as reflecting the views of the Board of Governors of the Federal Reserve System or of any other person associated with the Federal Reserve System.
} 
We use credit-arbitrage asset-backed commercial paper (credit-arb ABCP) vehicles to offer evidence on the reasons major banks exposed themselves to systematic bad-tail risk in the period leading up to the financial crisis that began in 2007. By systematic bad-tail risk we mean exposure to large losses in low-probability states of the world, especially states in which such losses are unusually costly, such as when risk premiums are high. In July of 2007, just before a run on their liabilities began, credit-arb ABCP vehicles had about $\$ 700$ billion in assets. Most were sponsored by banks that provided their vehicles with committed backup lines of credit and other support, so sponsors bore the vehicles' risks. When vehicles experiencing ABCP runoffs turned to their sponsors for funding, the sponsors sought large amounts of new funding in interbank and other money markets. Most sponsors were European banks but most vehicle assets and liabilities were denominated in U.S. dollars; thus, sponsoring banks were forced to raise funds outside their home money markets and their national central banks were not immediately able to provide dollar liquidity support. This increased the cost to sponsors and also helped transmit the ABCP shock throughout the global financial system. ${ }^{1}$

Many policy actions in response to the crisis are intended to affect risk-taking incentives or to impose constraints on risk taking. Understanding the reasons why financial institutions take systematic bad-tail risk is important to policy design as well as to their governance. Many studies have empirically examined bank risk taking (e.g. Keeley (1990), Laeven and Levine (2009), De Jonghe (2010), DeYoung and Torna (2012)), but such studies have largely focused on measures of the average risk from all projects, such as bank loan losses or equity volatility. The sharply defined nature of credit-arb vehicle risks allows us to empirically analyze bad-tail risk decisions by financial institutions, which to the best of our knowledge has not been done previously. Our

\footnotetext{
${ }^{1}$ Money markets play a key role not only in traditional intermediation of savings and investment, but also in arbitrage and financial engineering activity, so a shock to money markets has broad consequences.
} 
work is also related to recent work on rare disasters in the presence of heterogeneity, such as Chen, Joslin and Tran (2012), though we analyze risk decisions, not asset-pricing consequences; on causes and dynamics of the crisis (e.g. Brunnermeier (2009); Gorton (2010); Covitz, Liang and Suarez (2013)); on hedge fund risks, since credit-arb vehicles are similar to hedge funds in some respects (e.g. Fung and Hsieh (2001); Chan, Getmansky, Haas, and Lo (2006)), and on shadow banks (Adrian, Ashcraft, Boesky, and Pozsar (2010); Acharya, Schnabl, and Suarez (2012); Gorton, Metrick, Shleifer, and Tarullo (2010)).

Credit-arb ABCP vehicles are a useful setting for studying systematic bad-tail risk-taking decisions because systematic bad-tail risk was the main risk vehicles posed to sponsors. The vehicles combined maturity transformation and tail credit risk: Their investment strategy was to go long the high-grade credit spread with mismatched funding and very high leverage. They borrowed at the short end of the credit spread term structure by issuing ABCP and lent at intermediate and long maturities, primarily by investing in AAA and AA rated asset-backed securities. The vehicles themselves either had no equity and subordinated debt or had very small amounts. ${ }^{2}$ The vehicles were almost immune to all but two events: large declines in credit quality of high-grade asset-backed securities, or a prolonged loss of access to funding in the ABCP market. Such events were predictably more likely to occur in tandem with high risk premiums or broad disruptions in financial markets, and costs to sponsors of vehicle distress are especially large in such situations. The credit-arb vehicle strategies had some similarity to those of Long Term Capital Management (LTCM) and other fixed-income arbitrage strategies, which have been likened to "picking up nickels in front of a steamroller" because they produce low per-

\footnotetext{
${ }^{2}$ These characteristics also make the credit-arb vehicles different from typical bank activities. Although banks are commonly thought to borrow short and lend long, large banks engage in a diversified array of activities, their assets span the credit quality spectrum, and their exposure to common macroeconomic risks is mitigated by cyclical patterns in liability flows (Gatev, Schuermann, and Strahan 2009).
} 
unit returns with modest volatility in most states of the world but large negative returns in some states of the world (Duarte, Longstaff, and Yu (2007)).

Credit-arb ABCP vehicles are also useful because the risk-taking decision is sharply defined, observable, and not closely linked to the sponsoring bank's other businesses. Most credit-arb vehicles bought securities in the capital markets. Such vehicles typically did not buy loans issued by the sponsoring bank and thus sponsorship was not an integral element of the sponsor's lending businesses. Moreover, some large banks sponsored vehicles and others did not. Because large banks differ in ownership (government versus private; concentrated versus diffuse), governance characteristics, leverage, and regulatory treatment, we can use cross-sectional variation in the characteristics of actual and potential sponsors to evaluate the empirical relevance of hypotheses about determinants of sponsorship.

Prior literature has offered several potential explanations for systematic bad-tail risk-taking, including: government-induced distortions, agency problems and corporate governance failures, underestimation of risk (Calomiris (2009a); Coval, Jurek, and Stafford (2009)), and ex ante firstbest decisions that turned out poorly ex post. With regard to the latter, banks may simply have struck an ex ante reasonable risk-return balance. Even if profits were low, risks may have been commensurately low. Problems at ABCP vehicles may simply have been bad luck, and systemic consequences were an externality that did not affect bank decisions. We cannot formally reject the first-best and mis-estimation hypotheses, but informal evidence is not very supportive because profitability and volume trends seem incompatible with first-best and because events of the 1990s and 2000s demonstrated the risks. We do find evidence that distortions played a role. ${ }^{3}$

\footnotetext{
${ }^{3}$ There was recent historical experience of the relevant kinds of meltdowns. A fixed-income hedge fund blowup (LTCM) occurred less than ten years before sponsorship decisions were made, an asset-backed securities meltdown occurred in 1994 (collateralized mortgage obligations), and a commercial paper market meltdown occurred in 2001.
} 
Three hypotheses focus on government-related distortions: First, banks' risk-reward tradeoff may be altered by regulations (Acharya, Schnabl, and Suarez (2012)) or, second, by deposit insurance or other implicit or explicit government guarantees (the "safety net”) (Merton (1977); Keeley (1990); Gropp, Hakenes, and Schnabel (2011)). Third, government ownership or control of banks might also distort their decision-making (Dinc (2005)).

Another hypothesis is that decisions were distorted by agency problems. Gorton and Rosen (1995) suggest that low-skill bank managers may take negative-NPV bad-tail risks in order to boost earnings and avoid being fired (such managers accept a higher probability of being fired eventually in order to avoid being fired soon when low earnings reveal their type). Compensation-related problems may also be material. ${ }^{4}$ For example, a combination of opaque bank risk postures and incentive compensation may permit bank CEOs to boost their compensation by taking tail risk that shareholders cannot observe.

Our evidence implies that both government-induced distortions and agency problems are material motivations. We find strong evidence that government ownership or control of banks makes systematic bad-tail risk-taking more likely: A significant minority of vehicles was sponsored by German Landesbanks, which are government controlled. ${ }^{5}$ We find weak evidence that government safety nets for privately owned banks encouraged sponsorship. Safety nets are more valuable for more levered banks, and leverage is sometimes a significant predictor of sponsorship, with more-levered banks more likely to sponsor, but statistical significance is not robust. A measure of the likely degree of government support of distressed banks is also a

\footnotetext{
${ }^{4}$ Bannier, Feess, and Packham (2012); Fahlenbrach and Stulz (2011); and Diamond and Rajan (2009) are three among many relevant papers.

${ }^{5}$ Moreover, Landesbank-sponsored vehicles were more likely to be a relatively large fraction of the sponsor's assets, so the chance of severe distress at the sponsoring Landesbank as a result of vehicle distress was larger. However, it is not clear that governments chose to take the risks associated with ABCP vehicles their banks sponsored. It may be that governance of such banks was weak, in which case one might interpret behavior of government-controlled banks as an instance of owner-manager agency problems (Hau and Thum (2009)).
} 
significant predictor of sponsorship, but again not robustly so. Large banks were more likely to sponsor vehicles than medium-sized banks, and large banks are thought to be more likely to be treated as too-big-to-fail. ${ }^{6}$ However, size might also proxy for the severity of agency problems or for economies of scale in managing ABCP vehicles. ${ }^{7}$ Overall, the evidence offers some support for safety nets as one among several motivations for systematic bad-tail risk-taking but does not strongly confirm such a motivation.

Using differences in regulatory capital treatment of credit-arb ABCP vehicles in Europe and the United States, we find no evidence that regulation per se affected sponsorship decisions. Acharya, Schnabl, and Suarez (2012) offer evidence that exemptions from regulatory capital requirements encouraged banks to sponsor $\mathrm{ABCP}$ vehicles. Our findings are compatible with theirs because their empirics include all types of $\mathrm{ABCP}$ vehicles, most of which posed risks different from credit-arb vehicles. The most common pre-crisis ABCP vehicle was a "multiseller" vehicle that invested in short-term debt from diverse issuers. Multiseller vehicles were often a material element of the sponsoring bank's lending businesses. Maturity mismatches and liquidity risk associated with such vehicles were smaller than for credit-arb ABCP vehicles, as was systematic credit risk. ${ }^{8}$ Taken together, our evidence and that of Acharya, Schnabl, and Suarez (2012) implies that banks moved some of their lending into ABCP vehicles to escape capital requirements but that regulatory treatment was not a primary driver of the decision to take systematic bad-tail risk in the form of credit arbitrage vehicles.

\footnotetext{
${ }^{6}$ Carbo-Valverde, Kane, and Rodriguez-Fernandez (2011) show that, before the financial crisis began, large European and U.S. banks enjoyed higher ex-ante safety-net benefits.

${ }^{7}$ If vehicles must be larger than some minimum size to be profitable, and only large banks can comfortably provide the credit and liquidity backstops for large vehicles, then only large banks should be observed to sponsor.

${ }^{8}$ As noted in Covitz, Liang, and Suarez (2013), some multiseller ABCP vehicles experienced funding problems in the late summer of 2007. However, such problems were relatively short-lived as market participants became fully aware of the differences in investment strategy across types of vehicles. Many multiseller vehicles still exist today, but almost all credit-arb ABCP vehicles have disappeared.
} 
Using a subset of banks for which we have compensation and governance information, we find evidence that agency problems played a material role in sponsorship decisions. Banks with better compensation practices were less likely to sponsor risky $\mathrm{ABCP}$ vehicles. In contrast, banks without a large shareholder were more prone to sponsor these vehicles. Proxies for bank opaqueness are economically significant predictors of sponsorship. In particular, the scale of a bank's underwriting activity in asset-backed securities, as well as bank size, are important predictors of sponsorship. Relative to traditional lending, the risks associated with underwriting, trading, and related activities are more difficult for outsider shareholders to understand and govern.

As to why most sponsors of vehicles were European entities, our evidence implies that the majority of sponsors were global universal banks. Most such banks were headquartered in Europe, not the United States. In this sense, the popular perception that the financial crisis was caused entirely by U.S. banks and the U.S. financial system is misplaced. Although subprime mortgage loans were largely a U.S. phenomenon, the liquidity-shock vulnerability that made the crisis global and systemic was to some extent a product of European banks' risk-taking decisions.

The remainder of the paper is structured as follows. The first section describes ABCP vehicles and the risks they pose to sponsors, and also describes how credit-arb vehicles differ from others. The second section describes the data and the third presents results, while the fourth provides concluding remarks. 


\section{$1 \quad$ ABCP vehicles and Risks to Investors and Sponsors}

This section presents information that suggests the risks of credit-arb ABCP vehicles are primarily systematic bad-tail risk and that such risks are borne largely by sponsors. Other types of ABCP vehicles are briefly described.

\subsection{Vehicles designed to transfer risk to sponsor}

$\mathrm{ABCP}$ vehicles are designed to limit risks borne by $\mathrm{ABCP}$ investors in order to obtain low short-term funding costs, which are important to vehicle profitability. Obtaining A1/P1 ratings is a practical necessity. The details of what satisfies the rating agencies differ across vehicles, but broadly, risk mitigation is built into governing documents of a vehicle. Examples include hedging requirements, investment strategy restrictions, and requirements for third party guarantees, often from the vehicle's sponsor. ${ }^{9}$

Vehicles have no employees and no offices (see Gorton and Souleles (2005) for more about such firms). All vehicle operations are conducted by service providers, such as law firms and investment managers. The sponsor usually is the investment manager and receives most of the net revenue ("excess spread") from a vehicle after funding costs and operating expenses. The sponsor is the usual provider of committed backup liquidity lines that fund repayment of maturing $\mathrm{ABCP}$ if it cannot be rolled over. The sponsor provides credit enhancements for some types of vehicles.

Losses caused by bankruptcy of the sponsor are limited by making the ABCP vehicle a robot firm that is bankruptcy-remote from its sponsor. If the sponsor fails, vehicle investors have the sole claim on vehicle assets and are isolated from the sponsor's bankruptcy proceeding. Even though the vehicle is bankruptcy remote, the value of risk mitigation provided to ABCP investors

\footnotetext{
${ }^{9}$ For example, the interest payment streams from fixed-coupon assets are swapped into floating-rate equivalents in order to limit net asset value fluctuations associated with changes in risk-free interest rates. Foreign exchange risks are also hedged.
} 
by a sponsor's commitments is reduced if the sponsor's default risk rises, so distress at the sponsor is usually associated with increased spreads on vehicle liabilities or a refusal of ABCP investors to roll over maturing debt, which we will refer to as a run. If the sponsor does not fail but vehicle assets suffer losses, such losses are very likely to be borne by the sponsoring bank, either via the credit enhancements or the backup lines of credit they provide or due to implicit commitments. Acharya, Schnabl, and Suarez (2012) find that during the crisis banks realized over 97 percent of the total losses on assets of ABCP vehicles of all types.

\subsection{Types of vehicles}

Different types of ABCP vehicles have different investment strategies, different relationships with the sponsor's other businesses, and pose different risks to the sponsor. The right panel of Table I gives amounts of ABCP outstanding as of mid-2007 for different types of vehicles, with the top panel showing amounts for the types of vehicles we examine and the bottom panel covering other types. The table shows outstanding ABCP; as described below, SIVs also issued about $\$ 300$ billion of medium term notes (MTNs), bringing the aggregate size of credit-arb vehicles to about $\$ 700$ billion.

[Table I about here.]

\subsection{Credit arbitrage vehicles}

We focus on credit arbitrage vehicles, including securities arbitrage vehicles (SAVs) and structured investment vehicles (SIVs). Hybrid vehicles have portfolios that mix SAV and multiseller characteristics, but the ones included in our sample closely resemble SAVs. Creditarb vehicles invest in diversified portfolios of assets, mostly asset-backed securities (ABS), that

appeared to pose low credit risk (about 90 percent of assets were rated AAA and AA before the 
crisis and almost all the remainder were rated A). ${ }^{10}$ Such vehicles diversify by 1 ) investing in a variety of types of ABS and other bonds (see Figure 1), and 2) by virtue of the fact that each ABS is backed by a pool of loans that are diversified along some dimensions. Of course, they were still exposed to systematic risk.

[Figure 1 about here.]

\subsubsection{Securities arbitrage vehicles}

Investors in a securities arbitrage vehicle are effectively protected from default in any state of the world that does not involve a failure to perform by providers of backup commitments. SAVs are buy-and-hold entities that are governed by accrual accounting, that have corporate charters that forbid the sale of assets at less than par, and that do not employ mark-to-market measures of vehicle net asset value in governing the vehicle. ${ }^{11}$ As long as assets do not default and funding costs (including the effect of hedges) remain stable, such vehicles can be expected to produce fairly steady streams of net revenue for sponsors. Of course, ABCP investors may withdraw funding or demand higher spreads, either because of exogenous disruptions in money markets or because they perceive that the risk that they will bear losses has risen. Credit enhancements and committed backup lines of credit are key sources of investor confidence.

Details of credit enhancements varied across vehicles, but in most cases their purpose was to: 1) limit variation in vehicle net asset value associated with changes in ratings of individual assets in the vehicle's portfolio; and 2) to achieve a low risk that individual assets will default. For example, if an originally AAA asset is downgraded a little bit, the provider of the enhancement (typically the sponsoring bank) adds assets to the vehicle to restore net asset value. If the asset is

\footnotetext{
${ }^{10}$ For brevity, we use ABS to refer to the full menu of asset backed securities, including MBS, CDO, ABS, etc.

${ }^{11}$ Vehicle operations are conditional on net income in some cases. For example, if daily net income is negative for an extended period, the investment manager may be forbidden to buy new assets or the vehicle may go into liquidation.
} 
downgraded further, say below single-A, the terms of the enhancement give the provider an incentive to buy the asset out of the vehicle at par. In principle, ABCP investors bear the risk of a jump to default without an intervening downgrade, but such jumps are very rare for assets rated A or better, and liquidity backstops offer additional protection.

Liquidity backup lines of credit are also usually bought from the sponsor and are for the full amount of vehicle assets. If ABCP funding availability dries up for any reason, the provider of the line will pay off ABCP investors and assume the risks posed by portfolio assets. ${ }^{12}$

Thus, as a practical matter, the sponsor of a securities arbitrage vehicle effectively bears all of the credit, market, and liquidity risk associated with the vehicle's portfolio in states of the world in which the sponsor has not failed. This is systematic bad-tail risk: ABCP investors are likely to withdraw funding in only three circumstances: 1) An exogenous disruption in money markets, in which case the sponsoring bank is likely to be forced to enter interbank markets to fund the vehicle at a time when funding liquidity is impaired; 2) A sharp deterioration in the credit quality of a substantial fraction of vehicle assets, which is likely to occur only when market credit spreads are high and when buying vehicle assets at par will impose substantial mark-to-market losses on the sponsor; and 3) When doubts about the ability of the sponsor to meet its obligations to the vehicle arise. In the latter case, the sponsor's own distress is likely to be worsened by a need to attract interbank deposits to fund the vehicle. In August and September of 2007, both 1) and 2) occurred, while 3) occurred for some sponsors.

\subsubsection{SIVs}

SIVs have assets similar to SAVs but are funded by a tranche of subordinated notes that represents 4 to 8 percent of vehicle liabilities, by ABCP, and by medium-term notes (MTN).

\footnotetext{
${ }^{12}$ For SAV investors to suffer a credit loss, a variant of a double-default event must occur: The sponsoring bank must fail to meet its contractual obligations to the vehicle, and the value of vehicle assets must be insufficient to pay off investors as ABCP matures.
} 
Sponsors do not provide contractual credit enhancements. The ABCP and MTN are equal in priority and differ mainly in term to maturity. SIVs are governed by mark-to-market accounting with net asset value triggers that force the vehicle to stop investing and to enter a liquidation mode if the net asset value of the vehicle falls below preset percentages of the par value of liabilities. In some states of the world, a liquidation might permit holders of the ABCP and MTNs to be paid in full if they hold the debt to maturity; however, in other states of the world the subordinated debt would be wiped out and some hold-to-maturity ABCP and MTN investors would bear losses (of course, those that run early by failing to roll over maturing debt will avoid losses).

In principle, SIV liquidity risk is managed by matching maturities of assets and liabilities, with ABCP used to fund short-term mismatches and to allow some flexibility to buy and sell assets. Because maturity-matching limits liquidity risk, the vehicles purchase a liquidity backup line of credit covering only a portion of liabilities. Some SIVs may have used a higher proportion of $\mathrm{ABCP}$ than maturity-matching would have implied, making them more vulnerable to runs. A refusal of investors to roll over MTN funding would also effectively put a SIV into liquidation mode, since it would have to use cash from maturing assets to repay maturing MTNs.

SIV sponsors appeared less exposed to vehicle risks than sponsors of SAVs because they did not provide full contractual backups and they did not hold vehicles' subordinated notes. However, almost all bank-sponsored SIVs were rescued by their sponsors. In most cases, the sponsors bought all vehicle assets or injected assets to prevent net asset value from falling below liquidation trigger points. Perhaps sponsors would not have done so had they foreseen the severity of the crisis, but in late 2007 or early 2008 they honored implicit commitments to 
vehicle investors. Thus, in practice, they were exposed to the same systematic bad-tail risk as SAV sponsors.

\subsection{Types of vehicles omitted from empirical analysis}

We omit multi-seller vehicles from our analysis because most of them pool nonfinancial-firm receivables and other short-term assets and consequently have a smaller maturity mismatch between assets and liabilities. In addition, banks often use multi-seller vehicles as an element of their lending businesses (sometimes providing loans to clients via vehicles rather than onbalance-sheet loans). Thus, a bank's decision to sponsor a multiseller vehicle is not necessarily well-separated from its other businesses. Few multi-seller vehicles became deeply distressed, and most are still operating, whereas most SAVs and SIVs have disappeared.

We also omit single-seller vehicles. Though there was some diversity of single-seller assets and strategies, a typical single-seller vehicle was a holding pen for loans awaiting securitization. For example, a mortgage lender might issue securitizations only a few times a year and might "park" loans in its vehicle until securitization occurred. Such vehicles are not the result of a risktaking decision that is separate from the sponsor's other businesses.

Of the remaining types of vehicles shown in Table 1, some might involve systematic bad-tail risk-taking, but all have structures or are related to sponsors' businesses in ways that make them less useful candidates than credit-arb vehicles for our study of systematic bad-tail risk-taking.

\section{Data}

To examine the motivations that led banks to sponsor credit-arb vehicles, we need information on the characteristics of ABCP vehicles and their sponsors. We focus on the period ending in mid-2007. Data on ABCP vehicles are from Moody’s Investors Service (“Moody’s”), 
primarily from quarterly "Program Index" spreadsheets, which include information on the characteristics of all ABCP vehicles rated by Moody's. ${ }^{13}$ The spreadsheets capture well over 90 percent of global vehicles by assets. ${ }^{14}$ Figure 2 shows the amount of ABCP outstanding by vehicle type starting at year-end 1999. Growth in all vehicles' categories was positive until 2007. The increase in the total amount of ABCP outstanding accelerated after 2004. ABCP outstanding increased by a factor of five between 2000 and 2007 for the set of credit arbitrage vehicles included in our sample, a much larger increase than at other types of vehicles. After the crisis began in the summer of 2007, issuance and outstandings decreased sharply.

[Figure 2 about here.]

We use information from Moody's to determine each vehicle's sponsor. As noted previously, we include in our analysis only credit-arb vehicles sponsored by U.S. and European banks. We omit a small number of vehicles sponsored by nonbanks or Asian banks because we are unable to determine regulatory treatment of them or we are unable to find data on sponsor characteristics. We also omit a small number of vehicles sponsored by Canadian banks because liquidity backup lines of credit were structured differently in Canada than elsewhere. A comparison of the amounts of ABCP outstanding in the first and second columns of Table I for the second quarter of 2007 shows that our sample captures almost 90 percent of outstanding ABCP for securities arbitrage vehicles (including hybrid vehicles), but only about 65 percent of outstandings for SIVs (a few large SIVs were sponsored by U.K. nonbanks). ${ }^{15}$

\footnotetext{
${ }^{13}$ The spreadsheets include average amount of ABCP outstanding - issued in the U.S. and European commercial paper markets - each quarter. For commercial paper denominated in currencies other than the U.S. dollar, we convert the amount outstanding to nominal U.S. dollars using the historical exchange rates published by the Federal Reserve in Table H.10.

${ }^{14}$ Standard and Poors and Fitch are the other two major ABCP rating agencies in the United States.

15 "Hybrid" vehicles as classified by Moody's combined characteristics of SAVs and other vehicle types. We include in analysis only hybrids that were effectively SAVs. We exclude some vehicles classified as SAVs by Moody's where the vehicle invested mainly in securities originated by the sponsor, which for our purposes makes it more like a multi-seller vehicle.
} 
We obtain balance sheet and income statement data about sponsor banks from Bankscope. We collect annual data on sponsors' underwriting activity for high yield bonds, ABS, and mortgage backed securities (MBS) from Bloomberg and Dealogic’s DCM Analytics.

Figure 3 shows the amount of bank-sponsored credit arbitrage vehicle ABCP outstanding grouped by the domicile of the vehicles' sponsor. ABCP outstanding from European banksponsored vehicles grew rapidly from 2002. ${ }^{16}$ Vehicles sponsored by U.S. banks grew little and had about half the ABCP outstanding of European sponsored vehicles by June 2007.

[Figure 3 about here.]

To evaluate the propensity of banks to sponsor vehicles, we must include both sponsor and non-sponsor banks in the sample. We include all sponsors as well as non-sponsor banks with \$25 billion or more in total assets that were domiciled in the United States or in Europe. We do not include smaller banks because none of them sponsor the types of vehicles we analyze. Table II presents the number of sponsor and non-sponsor banks in each country in mid-2007. Germany has a relatively large number of sample banks and an especially large number of sponsor banks. Many German sponsors are government-owned or controlled, such as Landesbanken. As described below, we check robustness by excluding this group of banks from some specifications.

\section{[Table II about here.]}

Table III lists the sponsor banks. About one-fifth of sponsor banks are from the United States (8 banks), and the remainder are from Europe (27 banks, representing about 72 percent of sponsors). In most cases the vehicles are modest in size relative to sponsor bank assets. (The biggest outliers in this regard, IKB Bank and Sachsen Landesbank, both government-controlled,

\footnotetext{
${ }^{16}$ For the purpose of this paper, Europe includes all members in the EU-15 (the 15 Western European member countries of the European Union before its expansion in 2004) plus Norway and Switzerland.
} 
failed early in the crisis; results presented below are robust to their elimination from the sample.) As shown in column 6, only $\$ 48$ billion of a total of $\$ 347$ billion of ABCP outstanding at vehicles of the type we analyze was in U.S.-sponsored vehicles.

[Table III about here.]

For comparison, Table IV lists sample banks that are not sponsors. To limit the size of the table, only those with $\$ 150$ billion or more in total assets are shown. Banks that we perceive to be among the most widely known global banks are highlighted in bold face. Although there are several such banks in both tables, the proportion that we perceive to be widely known global banks is larger in Table III. ${ }^{17}$

[Table IV about here.]

When examining the role that government-induced distortions played in vehicle sponsorship, we use a bank-specific measure of government support similar to that in Brandao-Marques, Correa and Sapriza (2012). We exploit the fact that Moody's assigns two separate ratings to each bank that it covers. The bank financial strength rating (BFSR) is intended to measure the bank's intrinsic safety and is constructed to ignore external support that the bank might receive from any other entity (including the government). The bank deposit rating measures the bank's ability to repay its deposit obligations and incorporates both the BFSR and Moody's opinion of the likelihood and amount of external support. Our government support measure is defined as the difference (in rating notches) between a bank’s BFSR and its long-term foreign currency deposit rating.

We use several proxies for manager incentives and bank governance to test the importance of agency problems. The main executive compensation measure is from RiskMetrics Group's

\footnotetext{
${ }^{17}$ We classify 32 percent of the large non-sponsor banks (Table IV) as widely known, while 45 percent of the sponsor banks (Table III) are widely known.
} 
Corporate Governance Quotient (CGQ). We follow Aggarwal, Erel, Stulz, and Williamson (2010) and use the questions included in the CGQ index related to compensation and ownership. For each bank, we measure the percentage of compensation and ownership attributes that satisfy a threshold defined by the RiskMetrics Group. A higher value of Compensation Index means that the bank has established compensation practices that are more in line with some pre-defined standards. We also use the percent of shares held by individual insiders, collected from FactSet/Lionshares, as a measure of incentive alignment.

We follow Erkens, Hung, and Matos (2012) in creating three corporate governance indicators. One is the share of independent directors on a bank's board, calculated using data from BoardEx. A second is the share of institutional ownership at each bank, from FactSet/Lionshares. A third is concentration of ownership, denoted Widely Held and measured by an indicator variable equal to 1 if a bank does not have a single owner with voting shares larger than 10 percent, constructed from data from FactSet/Lionshares, Bankscope, and banks’ annual reports.

Finally, we also use information on the characteristics of banks' home countries, including measures of the degree of financial market development (stock market capitalization to GDP and private bond market capitalization to GDP) and macroeconomic performance (the annual average percent change of real GDP).

Table V reports summary statistics for our sample and Table VI examines how bank and country characteristics vary across sponsor and non-sponsor banks. ${ }^{18}$ Definitions and sources for each of the variables are in Appendix A. Table VI reveals some differences between sponsor

\footnotetext{
${ }^{18}$ Bankscope variables are measured as of the previous fiscal year-end. Approximately 95 percent of our sample has a December fiscal year end date. For the remaining banks, we associate fiscal years ending in January through March with the prior year and fiscal years ending in April through November with the current year. Consequently, financial variables for a bank with a March fiscal year are measured as of the current March, while financial variables for a bank with a September fiscal year are measured as of the previous September.
} 
and non-sponsor banks: As of June 2007, relative to non-sponsors, sponsor banks were larger, were more complex in their assets and activities, had smaller loan to assets and equity to assets ratios, and underwrote larger volumes of ABS and MBS. Of course, such characteristics may be correlated. In the next section we report results of probit regressions that examine the relationship between sponsorship and sponsor characteristics in more detail.

[Table V and VI about here.]

\section{$3 \quad$ Results for determinants of vehicle sponsorship}

In this section, we test hypotheses that distortions from government activities or from agency problems motivated banks' sponsorship of ABCP vehicles. We begin with informal evidence about the possibility that sponsorship decisions resulted from undistorted risk-return tradeoffs.

\subsection{Just bad luck}

Data are not available to support formal testing of a hypothesis that banks made entirely undistorted risk-reward decisions to sponsor credit-arb vehicles. However, in such a case, we would not expect evidence of government or agency distortions. Informal evidence also does not compellingly support it: Vehicle profitability appears low, and grew lower at the same time as vehicles expanded.

Profits are generally not disclosed, but the example of Mellon Bank gives a sense of vehicle profitability. At year-end 2006, Mellon's vehicle had $\$ 3.2$ billion in assets, which if consolidated would have increased Mellon's total assets by 7.7 percent (a large fraction). But the vehicle provided only $\$ 3$ million of gross revenue to the bank (10 basis points of vehicle assets). Somewhat unrealistically assuming that Mellon itself had no expenses associated with the vehicle (all revenue was net profit), the vehicle still contributed only 0.3 percent of Mellon's 
2006 net income. ${ }^{19}$ Similarly, Acharya, Schnabl, and Suarez (2012) note that Deutsche Bank’s 2007 annual report reveals that its vehicles generated €6 million of fees relative to commitments of $€ 6.3$ billion, again about 10 basis points before expenses.

In the aggregate, vehicles grew as profitability fell. Figure 4 plots a proxy for the gross spread earned on vehicle investments (the yield on ABS less LIBOR for two types of underlying assets; ABCP rates were generally close to LIBOR until the crisis hit). As shown in Figure 2, outstanding ABCP at credit-arb vehicles grew from 2004 on, while Figure 4 shows gross spreads fell to low levels during the same period. ${ }^{20}$ A bank increasing its commitment to a strategy the expected returns of which have fallen appears to be a violation of portfolio theory unless the risk associated with the vehicles fell even more rapidly than did gross spreads, or unless the returns to all other strategies have fallen more. As we argued previously, risks posed by the vehicles were almost entirely bad-tail risk borne by the sponsors, and such bad-tail risk does not vary much during booms (or perhaps is increasing). ${ }^{21}$ Overall, the volume and profitability data do not obviously imply that sponsorship decisions were undistorted.

[Figure 4 about here.]

\subsection{Regressions}

We use multivariate probit regressions to examine the effect of government and agency distortions on ABCP sponsorship. The dependent variable is an indicator equal to 1 for banks that sponsored at least one credit-arb vehicle and 0 otherwise. Specifically, we estimate

$$
\operatorname{Pr}\left(\text { Sponsor }_{i}=1\right)=F\left(\alpha+\beta \text { Bank Traits }_{i}+\gamma \text { Country Traits }_{i}\right)
$$

\footnotetext{
${ }^{19}$ By early 2008, Mellon had used "excess liquidity" to pay off ABCP investors and wind up the vehicle, taking the assets onto the bank's balance sheet.

${ }^{20}$ The pattern raises the possibility that bank managers tried to compensate for reduced per-unit revenue by increasing the size of vehicles, but we cannot verify such a conjecture.

${ }^{21}$ The vehicles are difficult to wind up, so a sponsor that increased vehicle size was committing to bear increased tail risk for many years.
} 
for each bank $i$ as of June 2007. Independent variables are measured, in most cases, as of the previous December. Specifications differ in the number of explanatory variables included.

Results presented in Table VII - XI shed light on variants of hypotheses and are discussed below. All but Table VIII report average marginal effects; consequently, coefficient magnitudes can be interpreted as the incremental probability of sponsorship. Standard errors (in parenthesis) are clustered at the country level. Table VIII shows the impact on probabilities of sponsoring an ABCP vehicle for large discrete changes in the values of some explanatory variables, using the model shown in column 2 of Table VII.

\section{[Tables VII and VIII about here.]}

We do not analyze determinants of credit-arb vehicle size. A barrier to empirical analysis is that the proper normalization is not obvious. ${ }^{22}$ We did run regressions of credit arbitrage vehicle assets as a fraction of the sponsor's total assets on the predictors shown in Table VII and they produced no evidence of robust predictors (not tabulated). Moreover, because vehicle size was modest relative to bank assets and in a modest range in most cases, its value as a measure of systematic bad-tail risk is not clear. In contrast, existence of sponsored vehicles was a signal to counterparties early in the crisis that a bank had taken systematic bad-tail risk, in addition to increasing the bank’s contingent funding needs and credit losses.

\subsection{Government-induced distortions}

We consider distortions associated with three kinds of government activity:

1) Capital regulations.

\footnotetext{
${ }^{22}$ Total assets of a bank's credit-arb vehicles relative to consolidated total assets of the sponsoring bank does not fully reflect both the capacity of the bank to obtain liquidity in the event of a run on the vehicles and its capacity to absorb credit losses in the event that vehicle assets have to be taken onto the bank's balance sheet. The literature has so far not put forward a convincing way to simultaneously measure both credit loss-bearing capacity and funding capacity in a way that is useful for studying credit-arb vehicle size.
} 
2) Safety nets: The loss-shifting ability of equity holders due to the existence of some combination of deposit insurance, regulatory forbearance, too-big-to-fail government bailouts of distressed banks, and other safety-net features.

3) Direct or indirect government ownership or control of banks. The governance mechanisms the government puts in place may lead to risk decisions that differ from undistorted decisions.

\subsubsection{Regulation per se}

We use differences in regulatory capital treatment in Europe and the United States to examine the impact of regulation. European banks were not required to have extra capital for the funding backstops and credit enhancements that most bank sponsors provided for their SAVs, but U.S. banks did face such requirements. That might account for the concentration of sponsors in Europe.

In 2001 and 2004, the United States adopted risk-based capital requirements for ABCP vehicle credit enhancements and for liquidity backstop lines of credit, respectively. Though the precise cost to banks of such requirements is not known, back-of-the-envelope calculations described in Appendix B imply that a capital-constrained bank would bear annual costs on the order of 2 basis points of SAV assets for each requirement, or 4 basis points in total, which is large relative to the profitability described previously and thus represented a significant disincentive to U.S. banks to sponsor SAVs.

Accounting rules were changed in 2003 to require consolidation of vehicle assets, but U.S. bank sponsors could escape U.S. leverage-ratio capital requirements by avoiding such consolidation, which they could do by purchasing "expected loss" protection from a third party. Our back-of-the-envelope calculations imply that such protection cost about 3 basis points of 
vehicle assets, though such costs are probably already reflected in the 10 basis point profit rate described previously (see Appendix B).

Given the cost differential, a hypothesis that regulatory capital treatment incentivized sponsorship implies that European banks should have been more likely to sponsor at the margin, after controlling for other characteristics. Results in column 2 of Table VII do not support this hypothesis: The average marginal effect for a dummy variable that is 1 for U.S. banks and 0 for European banks is positive rather than negative, near zero, and not statistically significantly different from zero. As discussed in Appendix B, the geographic differences in regulatory treatment were much more pronounced for SAVs than for SIVs. When we identify as sponsors only banks that sponsor at least one SAV, results for the U.S. dummy are similar (not tabulated). The greater propensity of European banks to sponsor may be due to other characteristics by which European banks differed from U.S. banks, such as size, presence of governmentcontrolled banks, and other characteristics. These are discussed further below.

An additional bit of circumstantial evidence that regulation per se was not a driver of sponsorship is that European banks' vehicles grew rapidly during 2004 to 2007 even though it was clear that the impending implementation of Basel II would soon implement risk-based capital requirements similar to those in the U.S. ABCP vehicles are difficult to wind up quickly, so the growth amounted to a pre-commitment by European banks to continue operations at scale even after Basel II implementation. Such a pre-commitment is inconsistent with regulatory capital incentives being a primary motivation for European banks to sponsor ABCP vehicles relative to U.S. banks. ${ }^{23}$

\footnotetext{
${ }^{23}$ Had they been in effect, high incremental capital requirements associated with bank sponsorship of credit-arb vehicles might have greatly reduced the extent of sponsorship. However, existence of low capital requirements alone is not necessarily the marginal motivation for sponsorship. We do not argue that capital requirements were irrelevant in principle, only that the evidence is more consistent with other factors driving decisions at the margin.
} 


\subsubsection{Government ownership or control}

Consistent with Brandao-Marques, Correa, and Sapriza (2012), we find strong evidence that direct or indirect government ownership or control was a factor in sponsorship. Almost all of the government-controlled banks in our sample are German Landesbanks, and the coefficient on Dummy Landesbank in Table VII is statistically and economically significant. The Landesbanks lost their formal government guarantee of liabilities in 2005, which might have motivated them to move their credit-arbitrage investment activity into $\mathrm{ABCP}$ vehicles (most had no vehicles or only small vehicles in 2000). Because large private banks also sponsored vehicles, government control is not the whole story of sponsorship, but it is does appear to be part of the story. We cannot identify whether government-controlled banks sponsored vehicles in order to conceal continued risk-taking from stakeholders (including the government) or due to government influence. In the former case, the activity might be characterized as a governance failure.

\subsubsection{Government safety nets}

Bank leverage is a commonly used proxy variable for distortions arising from government safety nets. A smaller equity-to-assets ratio is assumed to imply that a bank is closer to insolvency, so the safety net subsidy and thus the distorting effect on bank decisions is assumed to be larger. Of course, leverage may also be related to the severity of agency problems, so we also use the bank-specific measure of government support described previously. Higher values imply more support.

Results are mixed. In the full-sample specification shown in Tables VII and VIII, the equityto-assets ratio is a statistically and economically highly significant predictor of sponsorship. When the equity ratio increases from the $25^{\text {th }}$ percentile to the $75^{\text {th }}$ percentile, the probability of

Relatedly, Iannotta and Pennacchi (2012) argue that ratings-based regulations incentivizes financial firms to choose bonds that have more systematic risk. However, such a mechanism could not have driven systematic risk of creditarb vehicles because European sponsors' vehicles were not subject to such regulations. 
sponsorship decreases by about 0.2 , which is large relative to the unconditional probability of 0.24. Table IX reports results for the subsample for which the bank-specific measure of government support is available. Government Support is a positive, statistically and economically significant predictor for sponsorship. Using the model estimated in column 2, an increase from the $25^{\text {th }}$ percentile of Government Support to the $75^{\text {th }}$ percentile implies a 7 percent increase in the probability of sponsorship (not tabulated).

[Table IX about here.]

However, most of this effect is driven by German Landesbanks, which usually have high government support. If we exclude Landesbanks from the sample, the effect of Government Support drops by two-thirds and becomes statistically insignificant (not tabulated).

Consequently, results for Government Support can also be interpreted as evidence of distortions driven by government ownership or control rather than by safety nets available to all banks.

Moreover, the equity to assets ratio is not a significant predictor of sponsorship for the subsample reported in Table IX. This is a characteristic of the smaller sample, not of the presence of the government support measure. The subsample is smaller mainly because it excludes banks for which financial strength ratings are unavailable. However, the subsample includes most of the largest, globally active banks in the full sample. ${ }^{24}$

As reported in Table $\mathrm{X}$, when we exclude Landesbanks from the full sample, the equity to assets ratio continues to be a statistically significant predictor. When we limit the sample to European banks, it is at best weakly statistically significant, and when we drop Landesbanks

\footnotetext{
${ }^{24}$ The subsample disproportionately excludes U.S. banks, raising the possibility that equity-to-assets is proxying in part for geographic variations in equity-to-asset ratios, which might be driven by other factors. However, in untabulated results, we do not find interactions of the U.S. dummy with equity to assets to be significant or to materially affect other results.
} 
from the European subsample it is no longer statistically significant. It is also insignificant in a U.S. subsample (untabulated).

[Table $\mathrm{X}$ about here]

In summary, government-induced incentive distortions play an important role in banks’ decision to sponsor ABCP vehicles. We find strong evidence that government ownership or control influenced sponsorship decisions, no evidence that banks sponsored vehicles differentially in Europe and the United States due to regulatory capital requirements, and mixed, unrobust evidence that government safety nets may have encouraged banks to sponsor vehicles.

\subsection{Agency problems}

Owner-manager agency problems might reduce or increase risk-taking relative to shareholders' desires. On the one hand, senior executive wealth may be very exposed to their bank’s performance due to lack of diversification and, if executives are risk averse, they may therefore take too little risk in the absence of corrective actions by shareholders, such as tailored compensation functions (Smith and Stulz (1985)). On the other hand, compensation arrangements might provide incentives to take too much risk by rewarding earnings without regard to risk (e.g., John and John (1993); Diamond and Rajan (2009); Bannier, Feess, and Packham (2012)), or low-quality executives might increase risk in hopes that associated increases in short-term earnings will help them retain their jobs (Gorton and Rosen (1995); Saunders, Strock, and Travlos (1990)). If compensation arrangements or other mechanisms by which shareholders influence risk-taking differ across firms, managers' incentives and ability to sponsor vehicles might differ. ${ }^{25}$ Moreover, other things equal, the more difficult it is for

\footnotetext{
${ }^{25}$ Berger, Imbierowicz, and Rauch (2012) find that higher CEO ownership reduces the probability of bank default during the financial crisis. In contrast, Beltratti and Stulz (2012) show that banks with more shareholder-friendly boards have significantly worse stock performance during the financial crisis, and Fahlenbrach and Stulz (2011) find
} 
shareholders to monitor and exert control, the more that risk-taking may deviate from shareholders’ desired level.

\subsubsection{Compensation and governance proxies}

Table XI reports results using the same specification as in column 2 of Table VII, but adding measures of executive compensation and corporate governance practices within banks. ${ }^{26}$ The sample is smaller because such measures are not available for all banks (for example, no Landesbanks are included in this subsample). ${ }^{27}$ As shown in the first column of Table XI, higher values of Compensation Index, which imply better practices, are associated with a statistically and economically significant reduction in the probability of sponsorship. A move from the $25^{\text {th }}$ percentile to the $75^{\text {th }}$ percentile in the sample distribution for Compensation Index implies a decrease of 22 percentage points in the probability of sponsoring a credit arbitrage vehicle, which is economically large, similar to the impact of being a Landesbank.

\section{[Table XI about here.]}

We employ five measures of ownership or quality of corporate governance. Column 3 of Table XI shows that the share of independent directors is not significantly related to a bank's decision to sponsor a credit arbitrage vehicle. Columns 2, 4 and 5 show results for insider ownership, institutional ownership, and the degree of dispersion of share ownership, included one at a time, while column 6 shows results when all measures are included in the probit regression. Though the fraction of shares in the hands of institutional owners has a positive and statistically significant relationship with sponsorship when it is the only agency-related variable,

that CEOs with compensation packages that better align shareholder-CEO interests perform at best no better than CEOs with worse incentives during the crisis.

${ }^{26}$ With the exception of banks in the United States and United Kingdom, disclosure of detailed managerial compensation and insider ownership is not available for many banks in our sample.

${ }^{27}$ The one exception to this is column 5 of Table XI. The results in this column are robust to controlling for or excluding Landesbanks. 
it is not statistically significant in column $6 .^{28}$ Among the ownership variables, only Widely Held is statistically significant, with a more widely held bank having a larger probability of sponsorship (note that weaker significance in column 6 is partly a result of the smaller sample relative to column 5). This is consistent with a greater role for sponsorship if greater dispersion of ownership makes it more costly for shareholders to form coalitions to improve governance of the firm.

\subsubsection{Opaqueness and complexity}

The impact of compensation, governance and ownership on risk-taking may depend upon the opaqueness of the firm, with shareholders in more opaque firms having less success in governing managers (John, Saunders, and Senbet (2000)). We use three proxies for opacity and complexity: Volume of underwriting of complex securities, ratio of noninterest income to total assets, and bank size. We also include ratios of deposits to assets and loans to assets as control variables for portfolio composition. Caveats about these proxies are discussed further below.

With respect to underwriting, risks related to high-yield bonds are usually well known and measured. In contrast, ABS are more complex and their risks are harder for outsiders to evaluate. The greater the securitization underwriting activity, the more opaque the bank, and the more magnified the impact of any existing agency problems. If managers prefer to take too much risk, as is implied by our results for compensation discussed above, the likelihood of sponsoring credit-arb vehicles would be higher for more opaque firms.

As measures of High Yield Underwriting and Securitization Underwriting, we compute a logistic transformation of the total face value of debt of the given type underwritten by each bank during 2006, such that the resulting value on the $(0,1)$ interval is 0.5 where the amount is $\$ 12.5$

\footnotetext{
${ }^{28}$ Using the specification in column 4, an increase in institutional ownership from the 25th percentile to the 75th percentile is associated with a 16 percent increase in the probability of sponsorship.
} 
billion. ${ }^{29}$ We chose $\$ 12.5$ billion based on back-of-the-envelope calculations of revenue per dollar of debt underwritten and of the number of fixed-income staff that could be supported by such revenue. Results are robust to other specifications, such as dummy variables for banks with material underwriting volumes. However, if we use raw underwriting volume in combination with total assets as the measure of bank size, collinearity between bank size and underwriting becomes severe (large underwriters are also among the largest banks).

Returning to Table VII, we find that ABS underwriting is an economically and statistically significant predictor of sponsorship. High-yield (junk) bond underwriting does not predict sponsorship. In Table VIII, the second row reports results of comparing fitted values for the $50^{\text {th }}$ and $90^{\text {th }}$ percentiles of the ABS underwriting variable. As a practical matter, the $50^{\text {th }}$ percentile of underwriting activity has an amount underwritten of zero, so the change is from none to a substantial amount. The change in predicted probability of sponsorship is nearly 14 percent, which is economically large.

Banks that engage in substantial volumes of activity other than traditional deposit-taking and lending are usually more difficult to understand than traditional banks. To measure nontraditional activities, we use the ratio of non-interest income to assets. Tables VII and VIII show that the relationship between this measure and sponsorship is positive, but it is only marginally statistically significant and the economic magnitude is small.

Larger organizations are not necessarily more complex, but the correlation between size and complexity is arguably positive. We divide banks into terciles of total assets and include dummies for the middle and largest terciles (Dummy Intermediate Tercile and Dummy Top Tercile). The coefficient for the top tercile is always positive and economically and statistically

\footnotetext{
${ }^{29}$ We apply the following transformation: $Y=1 /\left(1+e^{-\left(\frac{X-12.5}{2.5}\right)}\right)$ where $X$ is the dollar value of ABS plus MBS underwriting measured in billions.
} 
significant. In the fourth row of Table VIII, fitted values are produced for the lowest and highest tercile, with the implied change in probability of moving from the small to the large category estimated to be 30 percent, a large effect. This result is robust to a variety of alternative measures of bank size, but we use terciles in the tabulated specifications because it limits problems of collinearity with other variables.

Of course, all of our proxies for opacity may also represent other things. Perhaps most importantly, economies of scale and scope may play a role in a bank's decision to sponsor vehicles. If setup and operation of a vehicle involves fixed costs, and given that net spreads per dollar invested were small, a positive net income constraint may have motivated banks to sponsor only vehicles of substantial size (few sponsors with vehicles totaling less than $\$ 2$ billion of assets appear in the data). Moreover, the sponsor must itself be large enough to convince the rating agencies that it can fulfill its commitment to support its vehicles. Since the sponsor was generally also the investment manager, economies of scope would exist if the sponsor already had on its payroll staff that was expert in fixed-income investments. ${ }^{30}$

Economies of scale cannot fully explain the strong effect of bank size on sponsorship because a number of medium-sized banks in our sample sponsored vehicles. Similarly, economies of scope are probably not the whole story behind the significance of underwriting measures. The last two rows in Table VIII show an exercise were we measure the change in the probability of sponsorship for small and large banks in the sample, when the levels of ABS underwriting increase from the $50^{\text {th }}$ percentile in the sample to the $90^{\text {th }}$ percentile. The change in

\footnotetext{
${ }^{30}$ A sizeable debt underwriter will typically house fixed-income dealing and trading units, fixed-income investment bankers that do issuance transactions, and specialized risk managers. Such individuals have the expertise to provide portfolio management services to the ABCP vehicles we study, but they are high-cost labor. Low underwriting activity likely implies a small staff of this type, which may not reliably have enough excess labor capacity to service vehicles. A larger staff may occasionally be fully occupied with underwriting and with trading for the bank's own account, but is more likely than a small staff to regularly have enough labor slack to be able to attend to a vehicle.
} 
the probability of sponsorship is more than twice as large for large banks when their level of underwriting increases. Size should not matter to scope economies, whereas banks that are both large and engaged in opaque activities seem particularly likely to be difficult to monitor and thus subject to owner-manager agency problems. Also note that high yield underwriting does not affect the decision to sponsor ABCP, but securitization underwriting strongly predicts sponsorship (see Table VII). We expect both types of underwriting to have similar economies of scope with credit-arb ABCP vehicles, but securitization underwriting is less transparent. Taken together, these results are consistent with agency problems as well as with economies of scale and scope.

\subsection{Other factors}

We include in regressions deposit-to-assets and loans-to-assets ratios as controls for the degree to which a bank engages in traditional activities. The marginal impact on the probability of sponsorship is sometimes weakly statistically significant, but the economic size of the relationships are small.

The last three rows of Table VII report results for variables that proxy for differences in national financial structure. Coefficients on such variables are generally statistically insignificant. Private Bond Market Capitalization is significant if the U.S. dummy is omitted, but as the U.S. bond market is by far the largest, this variable could be standing in for any of the differences between the United States and Europe.

\section{$4 \quad$ Concluding Remarks}

Overall, the combined evidence from probit regressions and from other facts and statistics suggests that a combination of government-controlled banks, agency problems, and perhaps 
safety nets and economies of scale and scope motivated bank decisions to take systematic badtail risk in the form of credit arbitrage $\mathrm{ABCP}$ vehicles. The fact that the majority of the western world's major universal banks sponsored vehicles is consistent with a view that relevant incentive distortions were widespread. Such risk-taking is of particular interest to designers of financial reform. We perceive that reforms to date have focused more on the impact of safety nets than on other factors. Our results imply that attention to government controlled banks and agency problems is also warranted. 


\section{References}

Acharya,Viral V., Gara Afonso, and Anna Kovner, 2012, How do global banks scramble for liquidity? Evidence from the asset-backed commercial paper freeze of 2007, Unpublished working paper, New York University.

Acharya, Viral and Matthew Richardson, 2009, Causes of the financial crisis, Critical Review 21, 195-210.

Acharya, Viral V. and Philipp Schnabl, 2010, Do global banks spread global imbalances? The case of ABCP during the financial crisis of 2007-09, IMF Economic Review 58, 37-73.

Acharya, Viral V., Philipp Schnabl, and Gustavo Suarez, 2012, Securitization without risk transfer, Journal of Financial Economics, forthcoming.

Adrian, Tobias, Adam B. Ashcraft, Haley Boesky, and Zoltan Pozsar, 2010, Shadow banking, Staff Report No. 458, Federal Reserve Bank of New York.

Aggarwal, Reena, Isil Erel, Rene Stulz, and Rohan Williamson, 2010, Differences in governance practices between U.S. and foreign firms: Measurement, causes, and consequences, Review of Financial Studies 23, 3131-3169.

Anderson, Ronald C. and Donald R. Fraser, 2000, Corporate control, bank risk taking and the health of the banking industry, Journal of Banking \& Finance 24, 1383-1398.

Bannier, Christina E, Eberhard Feess, and Natalie Packham, 2012, Competition, bonuses, and risk-taking in the banking industry, Review of Finance.

Beltratti, Andrea and René M. Stulz, 2012, The credit crisis around the globe: why did some banks perform better?, Journal of Financial Economics, forthcoming.

Bens, Daniel A. and Steven J. Monahan, 2008, Altering investment decisions to manage financial reporting outcomes: Asset-backed commercial paper conduits and FIN 46, Journal of Accounting Research, December.

Berger, Allen N., Björn Imbierowicz, and Christian Rauch, 2012, The role of corporate governance in bank failures during the recent financial crisis, Unpublished working paper, University of South Carolina.

Brandao Marques, Luis, Ricardo Correa, and Horacio Sapriza, 2012, International evidence on government support and risk-taking in the banking sector, European Banking Center Discussion Paper 2012-027, October.

Brunnermeier, Markus, 2009, Deciphering the liquidity and credit crunch of 2007-2008, Journal of Economic Perspectives 23, 77-100.

Calomiris, Charles, 2009a, Financial innovation, regulation, and reform, Cato Journal 29, 65-91. 
Calomiris, Charles, 2009b, The subprime turmoil: What's old, what's new, and what's next, The Journal of Structured Finance 15, 6-52.

Carbo-Valverde, Santiago, Edward J. Kane, and Francisco Rodriguez-Fernandez, 2011, Safetynet benefits conferred on difficult-to-fail-and-unwind banks in the US and EU before and during the great recession, NBER Working Paper No. 16787.

Chan, Nicholas, Mila Getmansky, Shane M. Haas and Andrew W. Lo, 2006, Systemic risk and hedge funds, in Mark Carey and Rene M. Stulz, eds., The Risks of Financial Institutions (University of Chicago Press).

Chen, Hui, Scott Joslin and Ngoc-Khanh Tran, 2012, Rare disasters and risk sharing with heterogeneous beliefs, Review of Financial Studies 25(7), 2189-2224.

Coval, Joshua, Jakub Jurek and Erik Stafford, 2009, The economics of structured finance, Journal of Economic Perspectives 23(1), 3-25.

Covitz, Daniel, Nellie Liang, and Gustavo Suarez, 2012, The evolution of a financial crisis: collapse of the asset-backed commercial paper market, Journal of Finance, forthcoming.

De Jonghe, Olivier, 2010, Back to the basics in banking: A micro analysis of banking system stability, Journal of Financial Intermediation 19, 387-417.

DeYoung, Robert, and Gokhan Torna, 2013, Nontraditional banking activities and bank failures during the financial crisis, Journal of Financial Intermediation forthcoming.

Diamond, D. W and R. G Rajan, 2009, The credit crisis: Conjectures about causes and remedies, The American Economic Review 99, 606-610.

Dinc, Serdar, 2005, Politicians and banks: Political influences on government-owned banks in emerging markets, Journal of Financial Economics 77, 453-479.

Duarte, Jefferson, Francis A. Longstaff, and Fan Yu, 2007, Risk and return in fixed income arbitrage: Nickels in front of a steamroller, Review of Financial Studies 20, 769-812.

Erel, Isil, Taylor D. Nadauld, and René M. Stulz, 2011, Why did U.S. banks invest in highlyrated securitization tranches?, NBER Working Paper No. 17269.

Erkens, David, Mingyi Hung, and Pedro Matos, 2012, Corporate governance in the 2007-2008 financial crisis: Evidence from financial institutions worldwide, Journal of Corporate Finance 18,389-411.

Fahlenbrach, Rüdiger and René M. Stulz, 2011, Bank CEO incentives and the credit crisis, Journal of Financial Economics 99, 11-26.

Federal Reserve Board, 2004, Agencies Issue Final Rule on Capital Requirements for ABCP Conduits, July 20. 
Fung, William, and David A. Hsieh, The risk in hedge fund strategies: Theory and evidence from trend followers, Review of Financial Studies 14(2), 313-341.

Gabaix, Xavier and Augustin Landier, 2008, Why Has CEO pay increased so much?, Quarterly Journal of Economics 123, 49-100.

Gatev, Evan, Til Schuermann and Philip E. Strahan, 2009, Managing bank liquidity risk: How deposit-lending synergies vary with market conditions, Review of Financial Studies 22(3), 995-1020.

Gennaioli, Nicola, Andrei Shleifer, and Robert W. Vishny, 2011, A model of shadow banking, NBER Working Paper No. 17115.

Gorton, Gary B., 2010, Slapped by the invisible hand: The panic of 2007 (Oxford University Press).

Gorton, Gary and Andrew Metrick, 2012, Securitized banking and the run on repo, Journal of Financial Economics 104, 425-451.

Gorton, Gary, Andrew Metrick, Andrei Shleifer, and Daniel Tarullo, 2010, Regulating the shadow banking system, Brookings Papers on Economic Activity, 261-312.

Gorton, Gary and Richard Rosen, 1995, Corporate control, portfolio choice, and the decline of banking, Journal of Finance 50, 1377-1420.

Gorton, Gary and Nicholas S. Souleles, 2005, Special purpose vehicles and securitization, NBER Working Paper No. 11190.

Gropp, Reint, Hendrik Hakenes, and Isabel Schnabel, 2011, Competition, risk-shifting, and public bail-out policies, Review of Financial Studies 24, 2084-2120.

Hau, Harald and Marcel Thum, 2009, Subprime crisis and board (in-) competence: Private vs. public banks in Germany, Economic Policy 24, 701-751

Iannotta, Guiliano and George Pennacchi, 2012, Bank regulation, credit ratings, and systematic risk, Working paper, November.

John, Teresa, and Kose John, 1993, Top management compensation and capital structure, Journal of Finance 48, 949-974.

John, Kose, Teresa A. John, and Lemma W. Senbet, 1991, Risk-shifting incentives of depository institutions: A new perspective on federal desposit insurance reform, Journal of Banking and Finance 15, 895-915.

John, Kose, Anthony Saunders, and Lemma W. Senbet, 2000, A theory of bank regulation and management compensation, Review of Financial Studies 13, 95-125.

JP Morgan Fixed Income Research, 2007, An ABCP cheat sheet, August 16. 
Kacperczyk, Marcin and Philipp Schnabl, 2010, When safe proved risky: Commercial paper during the financial crisis of 2007-2009, Journal of Economic Perspectives 24, 29-50.

Keeley, Michael C. , 1990, Deposit insurance, risk, and market power in banking, American Economic Review 80, 1183-1200.

Krishnamurthy, Arvind, Stefan Nagel, and Dmitry Orlov, 2012, Sizing up repo, NBER Working Paper No. 17768.

Laeven, Luc and Ross Levine, 2009, Bank governance, regulation and risk taking, Journal of Financial Economics 93, 259-275.

Merton, Robert C., 1977, An analytic derivation of the cost of deposit insurance and loan guarantees, Journal of Banking and Finance 1, 3-11.

Moody’s Investors Service, 2007, ABCP credit arbitrage snapshot, March 31.

Nadauld, Taylor and Shane M. Sherlund, 2012, The role of the securitization process in the expansion of subprime credit, Journal of Financial Economics, forthcoming.

Nadauld, Taylor D. and Michael S. Weisbach, 2011, Did securitization affect the cost of corporate debt?, Journal of Financial Economics, forthcoming.

Saunders, Anthony, Elizabeth Strock, and Nicholas G. Travlos, 1990, Ownership structure, deregulation, and bank risk taking, Journal of Finance 45, 643-654.

Smith, Clifford W., and Rene M. Stulz, 1985, The determinants of firms' hedging policies, Journal of Financial and Quantitative Analysis 20, 391-405. 


\section{Appendix A Variable Definitions}

This appendix defines the variables used throughout the paper.

\begin{tabular}{|c|c|}
\hline Variable & Definition \\
\hline Sponsor & $\begin{array}{l}\text { Dummy variable equal to } 1 \text { if the bank sponsored at least one SIV, securities } \\
\text { arbitrage, or hybrid ABCP vehicle during a given year. Source: Moody's } \\
\text { quarterly program index. }\end{array}$ \\
\hline Return on Assets & Net income divided by average assets. Source: Bankscope. \\
\hline Dummy Intermediate Tercile & $\begin{array}{l}\text { Dummy variable equal to } 1 \text { if the total assets of the bank are in the middle tercile } \\
\text { of the sample for a given year. Source: Bankscope. }\end{array}$ \\
\hline Dummy Top Tercile & $\begin{array}{l}\text { Dummy variable equal to } 1 \text { if the total assets of the bank are in the top tercile of } \\
\text { the sample for a given year. Source: Bankscope. }\end{array}$ \\
\hline Equity to Assets & Ratio of book equity to total assets. Source: Bankscope. \\
\hline Loans to Assets & Ratio of net loans to total assets. Source: Bankscope. \\
\hline Deposits to Assets & Ratio of deposits to total assets. Source: Bankscope. \\
\hline $\begin{array}{l}\text { Non-Interest Operating Income } \\
\text { to Assets }\end{array}$ & Ratio of non-interest operating income to total assets. Source: Bankscope. \\
\hline High Yield Underwriting & $\begin{array}{l}\text { Logistic transformation of the total face value (US\$) of high yield debt } \\
\text { underwritten by the bank during } 2006 \text {, such that the resulting value on the }(0,1) \\
\text { interval is } 0.5 \text { where the amount is } \$ 50 \text { billion. Source: Bloomberg, Dealogic } \\
\text { DCM Analytics. }\end{array}$ \\
\hline Securitization Underwriting & $\begin{array}{l}\text { Logistic transformation of the total face value (US\$) of asset-backed securities } \\
\text { and mortgage backed securities underwritten by the bank during } 2006 \text {, such that } \\
\text { the resulting value on the }(0,1) \text { interval is } 0.5 \text { where the amount is } \$ 50 \text { billion. } \\
\text { Source: Bloomberg, Dealogic DCM Analytics. }\end{array}$ \\
\hline Dummy Landesbank & $\begin{array}{l}\text { Dummy variable equal to } 1 \text { if the bank is a German Landesbank. Source: } \\
\text { Bankscope. }\end{array}$ \\
\hline Dummy US & $\begin{array}{l}\text { Dummy variable equal to } 1 \text { if the bank is domiciled in the United States. Source: } \\
\text { Bankscope. }\end{array}$ \\
\hline Government Support & $\begin{array}{l}\text { For each bank, Moody’s long-term foreign currency deposit rating minus } \\
\text { Moody’s bank financial strength rating (see Brandao-Marques, Correa and } \\
\text { Sapriza (2012)). Source: Moody’s Investors Services. }\end{array}$ \\
\hline Compensation Index & $\begin{array}{l}\text { The percentage of the bank's compensation and ownership attributes that satisfy } \\
\text { thresholds specified by RiskMetrics Group's Corporate Governance Quotient, } \\
\text { calculated as in Aggarwal et al. (2010). Source: RiskMetrics. }\end{array}$ \\
\hline Inside Ownership & Percent of shares owned by individual insiders. Source: FactSet/Lionshares. \\
\hline Board Independence & Share of independent directors on the bank's board of directors. Source: BoardEx. \\
\hline Institutional Ownership & Percent of shares owned by institutions. Source: FactSet/Lionshares. \\
\hline Widely Held & $\begin{array}{l}\text { Dummy variable equal to } 1 \text { if the bank does not have a single owner with voting } \\
\text { shares larger than } 10 \text { percent. Source: FactSet/Lionshares, Bankscope, Annual } \\
\text { Reports. }\end{array}$ \\
\hline Stock Market Cap. & $\begin{array}{l}\text { Ratio of stock market capitalization to GDP. Source: Worldscope, Bank for } \\
\text { International Settlements. }\end{array}$ \\
\hline Private Bond Market Cap. & $\begin{array}{l}\text { Ratio of private bond market capitalization to GDP. Source: Worldscope, Bank } \\
\text { for International Settlements. }\end{array}$ \\
\hline Real GDP Growth & $\begin{array}{l}\text { Annual average percent change of real GDP. Source: OECD, Bureau of } \\
\text { Economic Analysis. }\end{array}$ \\
\hline
\end{tabular}




\section{Appendix B: Regulatory treatment}

This appendix describes in more detail the regulatory capital requirements associated with credit arbitrage vehicles and rough estimates of the net profits required to cover the cost of incremental required equity capital. Our description is broadly similar to that in Acharya, Schnabl and Suarez (2012) except that they do not discuss capital requirements associated with credit enhancements, nor do they produce examples of costs of capital relative to profitability.

Capital requirements differed for SIVs and SAVs. Focusing first on SAVs, European banks incurred no incremental capital requirements by sponsoring a SAV through mid-2007. U.S. banks incurred regulatory risk-based capital requirements against credit enhancements beginning in 2002 and liquidity backstop lines of credits beginning in 2004, and beginning in 2004 their vehicles incurred costs associated with expected loss notes (ELNs) issued to avoid consolidation of vehicle assets onto the sponsor's balance sheet.

In a November 2001 rule that took effect as of January 1, 2002, U.S. bank regulators specified risk-based capital requirements for “direct credit substitutes," which included credit enhancements provided to ABCP vehicles (see Federal Register volume 66 page 59614). ${ }^{31}$ In the Basel 1 scheme in effect at the time, requirements were specified in terms of "risk weights" with the risk weight for a standard corporate loan or bond being 100 percent. Risk weights were then multiplied by a standard requirement to obtain dollars of capital per dollar of assets. Though 8 percent is the most widely reported standard requirement (8 cents of “total” capital per dollar of $100 \%$ risk weight assets), a more relevant U.S. requirement was 6 percent of Tier 1 capital to be "well capitalized” (because Tier 1 more closely approximated common equity).

\footnotetext{
${ }^{31}$ The substance of the rule, which required capital beyond that in Basel 1, was not adopted by the Basel Committee on Banking Supervision (BCBS) and thus was not part of the Basel 1 agreement: U.S. regulators adopted it unilaterally, though it foreshadowed treatment in Basel 2 (which, as a practical matter, was not implemented by any relevant banks until around the time the crisis started).
} 
Risk weights for credit-arb vehicle credit enhancements were applied to the face amount of the enhancement, which was commonly 10 percent of vehicle assets. The risk weight depended on the agency ratings of assets in the vehicle, with a 20 percent weight for AAA and AA assets and 50 percent weight for A rated assets. For example, for a vehicle with 80 percent of assets rated AAA or AA and the remainder A, the risk weight for the credit enhancement would be $0.8^{*} 0.2+$ $(1-0.8) * 0.5$ or 26 percent. Applying the weight to the credit enhancement size (10 percent of vehicle assets) and then multiplying by the standard 6 percent requirement yields required capital of $0.26 * 0.10 * 0.06=15.6$ basis points of Tier 1 capital per dollar of vehicle assets. Such capital is costly in that it has a higher required return than debt and it must be held in addition to the ABCP that comprises all of SAV liabilities (since the Tier 1 capital is not on the books of the SAV). Using a back-of-the-envelope 15 percent required return on equity capital, $.00156 * .15=2.3$ basis points of vehicle net profit is needed to compensate the sponsor for this regulatory requirement.

In a July 2004 rule to take effect September 2004, U.S. bank regulators specified risk-based capital regulatory treatment of ABCP liquidity facilities (see Federal Register volume 69 page 44908; see also Interagency Guidance issued August 4, 2005). This rule applied a 10 percent “credit conversion factor" (CCF) to "eligible" liquidity backstops and also specified that the face amount of any credit enhancement provided by the same bank could be subtracted from the face amount of the liquidity backstop before applying the CCF. The CCF is multiplied by the risk weight, which is rating-sensitive in a manner similar to that of credit enhancements. Continuing the example above, the risk weight for a typical liquidity backstop that equals 100 percent of the amount of vehicle assets, provided by the same bank that provides a 10 percent credit enhancement, would be $\mathrm{CCF}^{*}(100-10$ percent $) *$ BlendedRiskWeight or $0.10 * 0.90 * 0.26=2.34$ 
percent. Again multiplying by a 6 percent standard requirement and a 15 percent cost of Tier 1 capital yields 2.1 basis point of vehicle net profit needed to compensate the sponsor for the requirement, about the same as the cost for the credit enhancement.

In FIN 46R, the FASB required consolidation of ABCP vehicle assets onto sponsor balance sheets beginning in 2004. The U.S. leverage ratio capital requirements would have applied, requiring Tier 1 capital equal to 5 percent of vehicle assets. Although the same rule that specified risk-based capital requirements for liquidity backstops permitted banks not to consolidate vehicle assets when computing risk-based capital requirements, there was no exemption for calculation of leverage ratio capital requirements. However, as described in Bens and Monahan (2007), the FASB (and bank regulators) allowed deconsolidation in cases where a vehicle issued "expected loss notes" (ELNs) to third parties that would bear credit default losses on vehicle assets up to the estimated long-run average probability of default times loss given default on vehicle assets. Such deconsolidation permitted a bank to escape the leverage ratio requirement. Because the risk of principal losses on such notes was very high, required coupon payments were also high, reportedly approximately the same as the face amount of notes over the life of the notes. Thus, though the face amount of such notes was very small because of the low default risk on assets rated A or better, the cost was material. For example, PNC Bank's September 30, 2009 10Q states that its ELNs had a face value of about 14 basis points of vehicle assets. Assuming a five year life of the ELNs implies an annual cost of about 3 basis points.

Taken together, costs of risk-based capital requirements and of avoiding leverage ratio capital requirements for SAVs were probably around 7 basis points before the crisis $(2+2+3)$.

Of these, 3 basis points were expenses within the vehicle, and thus already netted from the Mellon Bank and Deutsche Bank examples which showed revenue before operating expenses of 
around 10 basis points. Though small in absolute terms, the remaining 4 basis points is substantial relative to 10 basis points and thus arguably represented a material disincentive for U.S. banks to sponsor SAVs. Two possible reasons why a few U.S. banks did so anyway are the agency problems discussed in the text and the possibility that some banks had "excess" Tier 1 capital and thus were not capital-constrained. Of course, the latter leaves open the question of why such banks did not return capital to shareholders.

Though the aforementioned estimates are back-of-the-envelope, the relevant features of regulation are known. Roughness in the estimates is from assumptions about the distribution of portfolio assets across rating categories and about banks' cost of capital. Though changes in such assumptions would change the estimates, moderate changes would not change the main points that regulatory capital costs of sponsorship were small in absolute magnitude but material relative to vehicle profitability.

Banks in all jurisdictions usually incurred no or almost no regulatory capital requirements from sponsoring SIVs because they usually did not own any of the SIV's subordinated notes and, if they provided liquidity backstop lines of credits, such lines totaled a modest fraction of total vehicle assets. SIVs were also structured to avoid consolidation. 


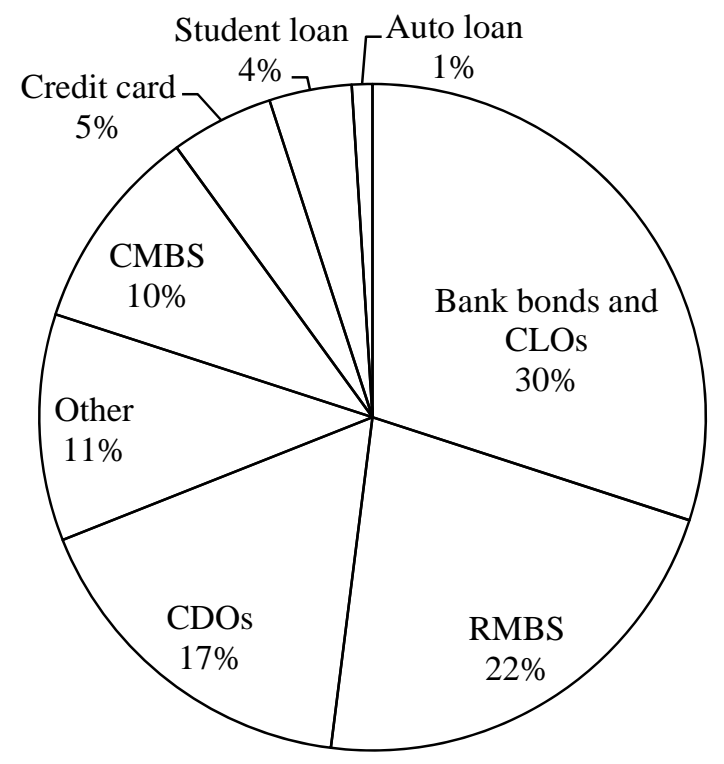

Figure 1. Credit arbitrage vehicle asset mix as of March 2007

This figure shows the percentage breakdown of each asset type held by the average credit arbitrage vehicle in March 2007. Source: Moody’s Investors Service. 


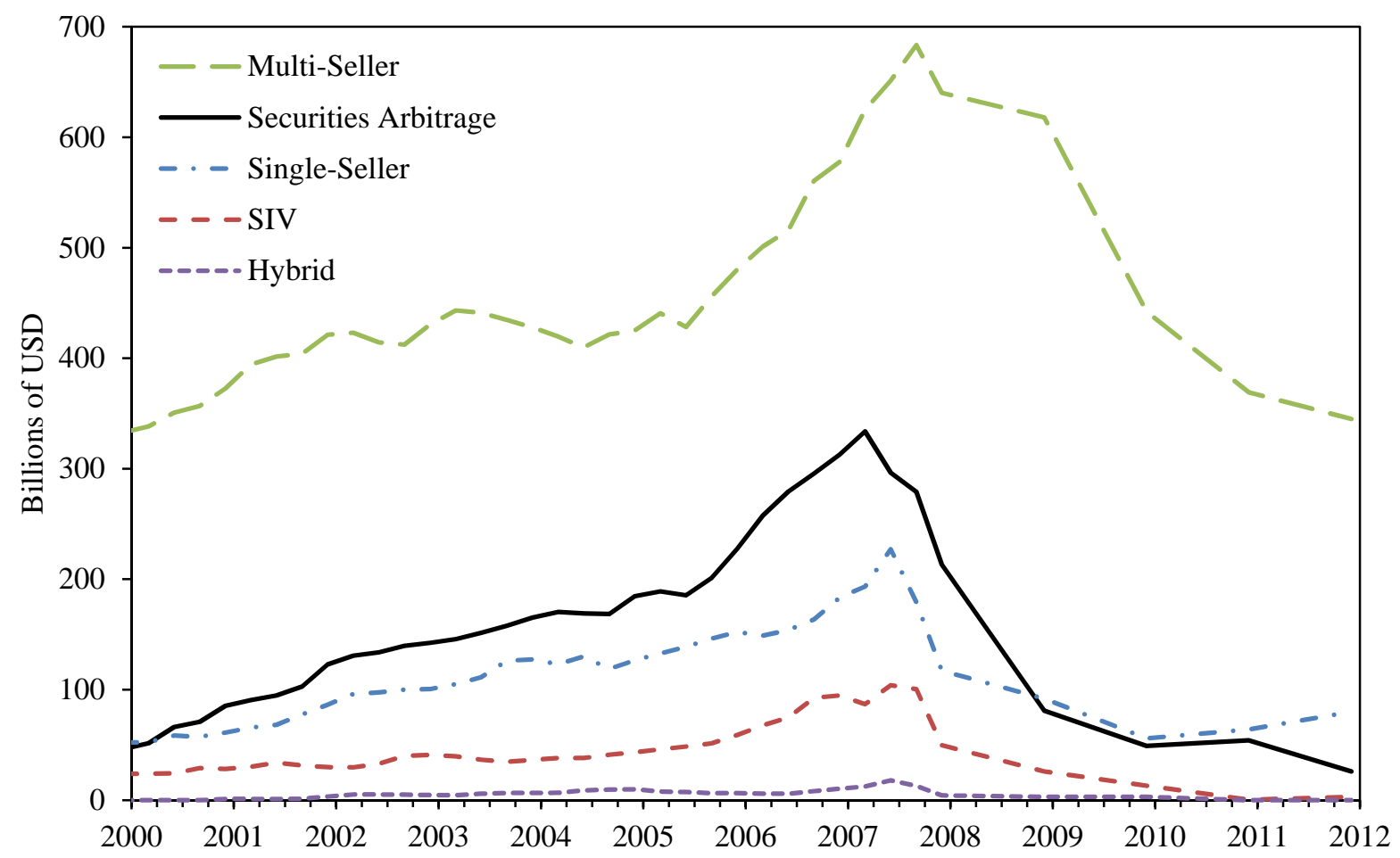

Figure 2. ABCP vehicle global $\mathrm{CP}$ outstanding by vehicle type

This figure shows the total quarterly amount of ABCP outstanding by vehicle type from December 1999 to December 2011. Source: Moody’s Investors Service. 


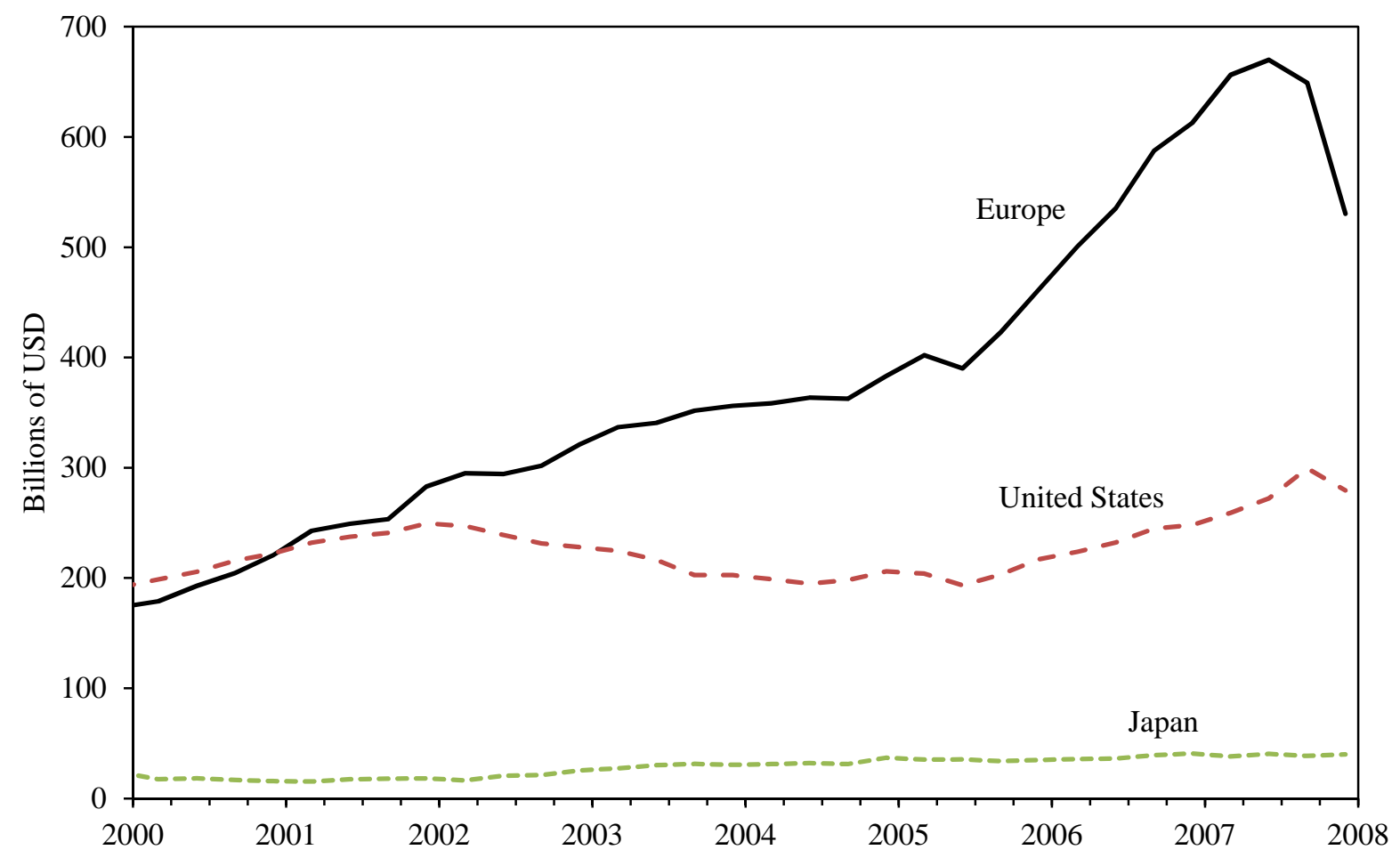

Figure 3. Global ABCP outstanding by region

This figure plots the total quarterly amount of ABCP outstanding grouped by the domicile of the vehicles' sponsor from December 1999 to December 2007. Only vehicles sponsored by banks are included. Europe is defined as all members in the EU-15 (the 15 Western European member countries of the European Union before its expansion in 2004) plus Norway and Switzerland. Source: Moody’s Investors Service. 


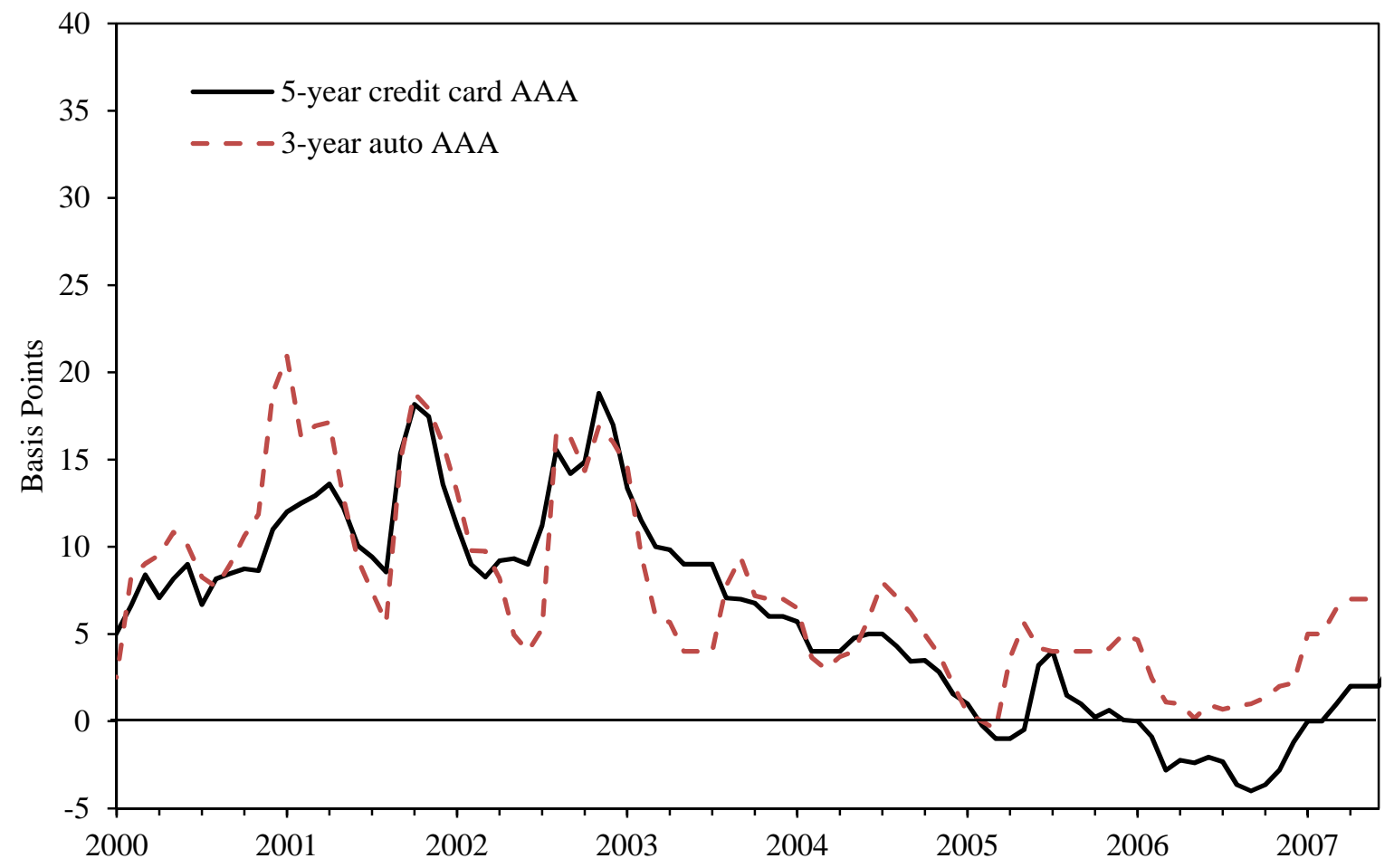

Figure 4. ABCP Interest Rate Spreads

This figure plots a proxy for the gross spread earned on ABCP vehicle investments from December 2009 to June 2007. The credit card spread represents the yield on 5-year AAA credit card asset backed securities (ABS) less LIBOR, while the auto spread is the yield on 3-year AAA automobile loan ABS less LIBOR. Source: Salomon Smith Barney and Citigroup Global Markets. 


\section{Table I}

\section{ABCP outstanding by vehicle type}

This table shows the total amount of asset backed commercial paper (ABCP) outstanding by vehicle type at the end of the second quarter of 2007, measured in millions of USD. The top panel shows ABCP outstanding for the types of vehicles that we study in this paper, while the bottom panel covers other types of vehicles. The first column examines vehicles sponsored by U.S. and European banks (the focus of this paper), while the second column shows total ABCP outstanding.

\begin{tabular}{lrr}
\hline & $\begin{array}{c}\text { Sponsored } \\
\text { by major } \\
\text { U.S. and } \\
\text { European } \\
\text { Banks }\end{array}$ & \multicolumn{1}{c}{ Total } \\
\hline Hybrid & 4,851 & 17,956 \\
Sec. Arbitrage & 274,426 & 296,347 \\
SIV & 66,831 & 104,094 \\
\hline Subtotal & 346,108 & 418,397 \\
\hline CDO & 2,642 & 68,833 \\
Loan-Backed & 3,539 & 3,539 \\
Multi-Seller & 456,125 & 651,224 \\
Repo/TRS & 4,979 & 83,251 \\
Single-Seller & 122,966 & 227,104 \\
Other & 5,806 & 11,936 \\
\hline Total & 942,165 & $1,464,284$ \\
\hline
\end{tabular}




\section{Table II \\ Number of banks with assets greater than $\$ 25$ billion by country}

This table presents counts of the number of sponsor and non-sponsor banks in each country at the end of the second quarter of 2007. To be included as a sponsor, a bank must sponsor at least one SIV, securities arbitrage, or hybrid ABCP vehicle. Non-sponsors must have at least \$25 billion in total assets to be part of our sample.

\begin{tabular}{lrrr}
\hline \multicolumn{3}{c}{ Banks by } \\
Country \\
\cline { 2 - 4 } & $\begin{array}{r}\text { Not } \\
\text { sponsoring } \\
\text { ABCP } \\
\text { vehicles }\end{array}$ & $\begin{array}{r}\text { Sponsoring } \\
\text { ABCP } \\
\text { vehicles }\end{array}$ & Total \\
\hline Austria & 4 & 0 & 4 \\
Belgium & 2 & 2 & 4 \\
Denmark & 1 & 1 & 2 \\
Finland & 2 & 0 & 2 \\
France & 12 & 2 & 14 \\
Germany & 14 & 11 & 25 \\
Greece & 5 & 0 & 5 \\
Ireland & 5 & 0 & 5 \\
Italy & 12 & 1 & 13 \\
Luxembourg & 1 & 0 & 1 \\
Netherlands & 4 & 4 & 8 \\
Norway & 1 & 0 & 1 \\
Portugal & 3 & 0 & 3 \\
Spain & 7 & 0 & 7 \\
Sweden & 4 & 0 & 4 \\
Switzerland & 4 & 0 & 4 \\
United Kingdom & 5 & 6 & 11 \\
United States & 27 & 8 & 35 \\
\hline Total & $\mathbf{1 1 3}$ & $\mathbf{3 5}$ & $\mathbf{1 4 8}$ \\
\hline
\end{tabular}


Table III

\section{List of banks sponsoring credit-arb ABCP vehicles}

This table lists the sponsor banks in our sample at the end of the second quarter of 2007. A sponsor bank is required to sponsor at least one SIV, securities arbitrage, or hybrid ABCP vehicle. Banks that we perceive to be widely recognized global banks are shown in boldface.

\begin{tabular}{|c|c|c|c|}
\hline & \multicolumn{3}{|c|}{ Second quarter 2007} \\
\hline & $\begin{array}{r}\text { ABCP } \\
\text { vehicles }\end{array}$ & $\begin{array}{r}\text { Total ABCP } \\
\text { (\$US Millions) }\end{array}$ & $\begin{array}{l}\text { Total ABCP to } \\
\text { total assets (\%) }\end{array}$ \\
\hline \multicolumn{4}{|l|}{ European Banks } \\
\hline ABN Amro & 1 & 9,263 & 0.7 \\
\hline Abbey National & - & - & - \\
\hline Barclays & 1 & 3,840 & 0.2 \\
\hline Bayerische Hypo-und Vereinsbank & - & - & - \\
\hline Bayerische Landesbank & 2 & 12,687 & 2.9 \\
\hline BNP Paribas & - & - & - \\
\hline Commerzbank & 1 & 1,007 & 0.1 \\
\hline Danske Bank & 1 & 2,500 & 0.5 \\
\hline Deutsche Bank & 2 & 6,391 & 0.4 \\
\hline Deutsche Zentral & 1 & 4,033 & 0.7 \\
\hline Dexia & - & - & - \\
\hline Dresdner Bank & 1 & 5,292 & 0.7 \\
\hline Erste Bank & - & - & - \\
\hline Fortis & 1 & 26,375 & 2.6 \\
\hline HBOS & 1 & 36,002 & 3.1 \\
\hline HSBC Holdings & 3 & 32,918 & 1.8 \\
\hline HSH Nordbank & 2 & 9,174 & 3.7 \\
\hline IKB Deutsche Industriebank & 1 & 18,577 & 22.0 \\
\hline ING Groep & 2 & 10,964 & 0.7 \\
\hline KBC Group & 2 & 4,266 & 1.0 \\
\hline Landesbank Baden-Wuerttemberg & 1 & 9,113 & 1.7 \\
\hline Landesbank Berlin Holding & 1 & 2,138 & 1.1 \\
\hline Lloyds TSB Group & 1 & 22,889 & 3.4 \\
\hline Nationwide Building Society & 1 & 2,936 & 1.4 \\
\hline Natixis & 1 & 2,820 & 0.5 \\
\hline NIBC Holding & 1 & 506 & 1.2 \\
\hline Rabobank Group & 5 & 15,181 & 2.1 \\
\hline Sachsen LB & 1 & 17,875 & 23.1 \\
\hline Société Générale & 1 & 724 & 0.1 \\
\hline Standard Chartered & 2 & 6,205 & 2.3 \\
\hline UniCredito Italiano & 1 & 19,289 & 1.8 \\
\hline WestLB & 3 & 16,096 & 4.3 \\
\hline Subtotal & 41 & 299,061 & \\
\hline \multicolumn{4}{|l|}{ U.S. Banks } \\
\hline Bank of America & 3 & 2,685 & 0.2 \\
\hline Bank of New York & 1 & 139 & 0.2 \\
\hline Citigroup Inc & 7 & 26,021 & 1.4 \\
\hline JP Morgan Chase \& Co. ${ }^{\text {a }}$ & 1 & 3,352 & 0.2 \\
\hline Mellon Bank & 1 & 3,790 & 14.5 \\
\hline State Street Corporation & 1 & 4,188 & 3.9 \\
\hline Wachovia Corporation & 1 & 3,641 & 0.5 \\
\hline Zions Bancorporation & 1 & 3,736 & 8.0 \\
\hline Subtotal & 16 & 47,552 & \\
\hline Total & 57 & 346,613 & \\
\hline
\end{tabular}




\section{Table IV}

\section{List of banks with total assets above $\$ 150$ billion not sponsoring credit-arb ABCP vehicles}

This table lists major European and U.S. banks that did not sponsor SIV, securities arbitrage, or hybrid ABCP vehicles. To limit the size of the table, only banks with $\$ 150$ billion or more in total assets are shown. Banks that we perceive to be widely recognized global banks are shown in boldface.

\begin{tabular}{l}
\hline European Banks \\
\hline Allied Irish Banks \\
Banco Bilbao Vizcaya Argentaria \\
Banco Santander \\
Bank of Ireland \\
BNP Paribas \\
Caisse Nationale des Caisses d'Epargne \\
Cassa Depositi e Prestiti \\
Credit Mutuel Centre Est Europe \\
Credit Suisse Group \\
Crédit Agricole Group \\
Deutsche Postbank \\
Dexia \\
DnB Nor \\
Groupe Banques Populaires \\
Gruppo Monte dei Paschi di Siena-Banca \\
Hypo Real Estate Holding \\
Intesa Sanpaolo \\
KfW Group \\
Landesbank Hessen-Thueringen Girozentra \\
Norddeutsche Landesbank Girozentrale NO \\
Nordea Bank \\
Northern Rock \\
Royal Bank of Scotland \\
Skandinaviska Enskilda Banken \\
Svenska Handelsbanken \\
UBI Banca-Unione di Banche Italiane \\
UBS \\
\hline U.S. Banks \\
\hline SunTrust Banks \\
US Bancorp \\
Washington Mutual Inc. \\
Wells Fargo \& Company \\
\hline
\end{tabular}




\section{Table V \\ Sample summary statistics}

This table presents summary statistics for the variables used in our analysis. The sample consists of all banks domiciled in the United States or in Europe with at least $\$ 25$ billion dollars in total assets. Sponsor is a dummy variable equal to one if the bank sponsored at least one SIV, securities arbitrage, or hybrid ABCP vehicle as of June 2007. The remaining variables are measured as of December 2006; definitions for each variable are found in Appendix A.

\begin{tabular}{lcccccc}
\hline & $\mathrm{N}$ & Mean & Median & Std Dev & Min & Max \\
\hline Sponsor & 148 & 0.24 & 0.00 & 0.43 & 0.00 & 1.00 \\
Return on Assets & 147 & 0.88 & 0.80 & 0.54 & 0.06 & 3.07 \\
Total Assets & 148 & 333.40 & 101.33 & 484.40 & 25.09 & 1956.71 \\
Equity to Assets & 148 & 6.31 & 5.97 & 3.36 & 1.44 & 19.07 \\
Loans to Assets & 148 & 52.85 & 58.19 & 20.47 & 0.26 & 93.07 \\
Deposits to Assets & 146 & 54.31 & 58.13 & 18.37 & 0.18 & 93.58 \\
Non-Interest Operating & 147 & 1.52 & 1.25 & 1.44 & -0.13 & 8.17 \\
Income to Assets & & & & & & \\
High Yield Underwriting & 148 & 0.04 & 0.01 & 0.16 & 0.01 & 1.00 \\
Securitization & 148 & 0.11 & 0.01 & 0.29 & 0.01 & 1.00 \\
Underwriting & & & & & & \\
Dummy Landesbank & 148 & 0.06 & 0.00 & 0.24 & 0.00 & 1.00 \\
Dummy US & 148 & 0.24 & 0.00 & 0.43 & 0.00 & 1.00 \\
Stock Market Cap. & 148 & 123.45 & 119.95 & 68.36 & 54.14 & 384.66 \\
Private Bond Market Cap. & 147 & 58.37 & 41.03 & 39.19 & 5.25 & 137.83 \\
Real GDP Growth & 148 & 3.05 & 2.87 & 0.87 & 1.30 & 6.12 \\
Government Support & 91 & 0.78 & 0.00 & 1.71 & -1.00 & 8.25 \\
Compensation Index & 89 & 65.34 & 62.50 & 22.66 & 14.29 & 100.00 \\
Insider Ownership & 85 & 0.02 & 0.00 & 0.05 & 0.00 & 0.40 \\
Board Independence & 97 & 0.75 & 0.80 & 0.17 & 0.34 & 1.00 \\
Institutional Ownership & 86 & 0.36 & 0.34 & 0.22 & 0.01 & 0.81 \\
Widely Held & 148 & 0.49 & 0.00 & 0.50 & 0.00 & 1.00 \\
\hline & & & & & & \\
\hline
\end{tabular}




\section{Table VI}

\section{Bank Characteristics by sponsorship decision}

This table reports the mean value as of December 2006 of the independent variables used in our regression analysis for banks that sponsored at least one SIV, securities arbitrage, or hybrid ABCP vehicle as of June 2007 and banks that did not sponsor any of these vehicle types. The sample consists of all banks domiciled in the United States or in Europe with at least $\$ 25$ billion dollars in total assets. We also report the difference in means between sponsor and non-sponsor banks and perform a two-sample t test to determine if this difference is statistically significant; standard errors are shown in parenthesis. ${ }^{* * *}$ indicates significance at the $1 \%$ level, $* *$ indicates significance at the $5 \%$ level, and * indicates significance at the $10 \%$ level. Definitions for the variables are found in Appendix A.

\begin{tabular}{|c|c|c|c|}
\hline & Sponsor & Non-Sponsor & Difference \\
\hline Return on Assets & 0.745 & 0.929 & $\begin{array}{l}-0.183^{*} \\
(0.106)\end{array}$ \\
\hline Total Assets & 739.627 & 207.579 & $\begin{array}{l}532.048^{* * * *} \\
(105.888)\end{array}$ \\
\hline Equity to Assets & 4.829 & 6.764 & $\begin{array}{c}-1.935^{* * *} \\
(0.548)\end{array}$ \\
\hline Loans to Assets & 41.701 & 56.297 & $\begin{array}{c}-14.596^{* * *} \\
(3.485)\end{array}$ \\
\hline Deposits to Assets & 54.263 & 54.328 & $\begin{array}{l}-0.065 \\
(2.852)\end{array}$ \\
\hline $\begin{array}{l}\text { Non-Interest Operating } \\
\text { Income to Assets }\end{array}$ & 1.601 & 1.490 & $\begin{array}{c}0.111 \\
(0.279)\end{array}$ \\
\hline High Yield Underwriting & 0.107 & 0.018 & $\begin{array}{l}0.089^{*} \\
(0.049)\end{array}$ \\
\hline Securitization Underwriting & 0.321 & 0.043 & $\begin{array}{l}0.278^{* * *} \\
(0.076)\end{array}$ \\
\hline Dummy Landesbank & 0.171 & 0.027 & $\begin{array}{l}0.145^{* *} \\
(0.066)\end{array}$ \\
\hline Dummy US & 0.229 & 0.239 & $\begin{array}{l}-0.010 \\
(0.083)\end{array}$ \\
\hline Stock Market Cap. & 131.692 & 120.894 & $\begin{array}{c}10.798 \\
(12.675)\end{array}$ \\
\hline Private Bond Market Cap. & 57.790 & 58.547 & $\begin{array}{l}-0.757 \\
(7.914)\end{array}$ \\
\hline Real GDP Growth & 2.904 & 3.091 & $\begin{array}{l}-0.187^{*} \\
(0.104)\end{array}$ \\
\hline Government Support & 1.509 & 0.467 & $\begin{array}{l}1.042^{* *} \\
(0.505)\end{array}$ \\
\hline Compensation Index & 61.716 & 66.758 & $\begin{array}{l}-5.042 \\
(5.522)\end{array}$ \\
\hline Insider Ownership & 0.009 & 0.028 & $\begin{array}{l}-0.019^{* *} \\
(0.009)\end{array}$ \\
\hline Board Independence & 0.715 & 0.756 & $\begin{array}{l}-0.041 \\
(0.042)\end{array}$ \\
\hline Institutional Ownership & 0.435 & 0.332 & $\begin{array}{l}0.103^{*} \\
(0.058)\end{array}$ \\
\hline Widely Held & 0.600 & 0.460 & $\begin{array}{c}0.140 \\
(0.096)\end{array}$ \\
\hline Observations & 35 & 113 & 148 \\
\hline
\end{tabular}




\section{Table VII \\ Full-sample results from probit models of sponsorship}

This table shows the results from estimating a probit regression in which the dependent variable is a binary indicator equal to 1 for banks that sponsored at least one SIV, securities arbitrage, or hybrid ABCP vehicle. We examine sponsorship as of June 2007. Most independent variables are measured as of December of the previous year. The values in the table represent average marginal effects. Definitions for the independent variables are found in Appendix A. Standard errors (shown in parenthesis) are clustered at the country level. *** indicates significance at the $1 \%$ level, $* *$ indicates significance at the $5 \%$ level, and * indicates significance at the $10 \%$ level.

\begin{tabular}{|c|c|c|}
\hline Dependent Variable & \multicolumn{2}{|c|}{ Sponsoring a Credit Arbitrage ABCP Vehicle $=1$} \\
\hline Year & $\begin{array}{c}(1) \\
2007 \\
\end{array}$ & $\begin{array}{c}(2) \\
2007 \\
\end{array}$ \\
\hline Return on Assets & $\begin{array}{c}-0.045 \\
(0.085)\end{array}$ & $\begin{array}{l}-0.023 \\
(0.075)\end{array}$ \\
\hline Dummy Intermediate Tercile & $\begin{array}{c}0.023 \\
(0.061)\end{array}$ & $\begin{array}{c}0.034 \\
(0.050)\end{array}$ \\
\hline Dummy Top Tercile & $\begin{array}{c}0.235^{* * *} \\
(0.082)\end{array}$ & $\begin{array}{c}0.234^{* * *} \\
(0.084)\end{array}$ \\
\hline Equity to Assets & $\begin{array}{c}-0.028^{* *} \\
(0.011)\end{array}$ & $\begin{array}{c}-0.033^{* * *} \\
(0.011)\end{array}$ \\
\hline Loans to Assets & $\begin{array}{l}-0.000 \\
(0.003)\end{array}$ & $\begin{array}{c}-0.001 \\
(0.003)\end{array}$ \\
\hline Deposits to Assets & $\begin{array}{l}-0.000 \\
(0.001)\end{array}$ & $\begin{array}{c}0.000 \\
(0.001)\end{array}$ \\
\hline Non-Interest Operating Income to Assets & $\begin{array}{l}0.044^{*} \\
(0.024)\end{array}$ & $\begin{array}{l}0.035^{*} \\
(0.021)\end{array}$ \\
\hline High Yield Underwriting & $\begin{array}{c}-0.001 \\
(0.145)\end{array}$ & $\begin{array}{l}-0.011 \\
(0.127)\end{array}$ \\
\hline Securitization Underwriting & $\begin{array}{l}0.165^{* * *} \\
(0.040)\end{array}$ & $\begin{array}{l}0.145^{* *} \\
(0.055)\end{array}$ \\
\hline Dummy Landesbank & $\begin{array}{l}0.222^{* * *} \\
(0.047)\end{array}$ & $\begin{array}{c}0.241^{* * *} \\
(0.062)\end{array}$ \\
\hline Dummy US & $\begin{array}{l}0.152^{*} \\
(0.079)\end{array}$ & $\begin{array}{c}0.047 \\
(0.178)\end{array}$ \\
\hline Stock Market Cap. & & $\begin{array}{c}0.000 \\
(0.001)\end{array}$ \\
\hline Private Bond Market Cap. & & $\begin{array}{c}0.002 \\
(0.002)\end{array}$ \\
\hline Real GDP Growth & & $\begin{array}{l}-0.055 \\
(0.052)\end{array}$ \\
\hline Observations & 145 & 144 \\
\hline Countries & 18 & 17 \\
\hline Pseudo $\mathrm{R}^{2}$ & 0.325 & 0.338 \\
\hline
\end{tabular}




\section{Table VIII}

\section{Changes in the probability of establishing an ABCP vehicle given discrete changes in selected explanatory variables}

This table reports changes in the probability of sponsoring at least one SIV, securities arbitrage, or hybrid ABCP vehicle for discrete changes in selected explanatory variables. All other variables are evaluated at the mean for the full sample. We estimate changes in probability using the model shown in column (2) of Table VII. Standard errors are clustered at the country level.

\begin{tabular}{|c|c|c|c|c|}
\hline & $\begin{array}{c}\text { Probability of } \\
\text { Risky ABCP } \\
\text { vehicle=1 (Initial } \\
\text { value for X } \\
\text { variable) }\end{array}$ & $\begin{array}{c}\text { Probability of } \\
\text { Risky ABCP } \\
\text { Vehicle=1 (Final } \\
\text { value for X } \\
\text { variable) }\end{array}$ & $\begin{array}{c}\text { Change in the } \\
\text { Probability of } \\
\text { Risky ABCP } \\
\text { vehicle=1 }\end{array}$ & $\begin{array}{c}\text { Confidence } \\
\text { Interval (95\%) }\end{array}$ \\
\hline $\begin{array}{l}\text { Change in Equity to Assets } \\
\text { from 25th perc. to 75th perc. } \\
\text { in } 2007\end{array}$ & 0.288 & 0.086 & -0.202 & {$[-0.338,-0.066]$} \\
\hline $\begin{array}{l}\text { Change in Securitization } \\
\text { Underwriting from 50th perc. } \\
\text { to 90th perc. in } 2007\end{array}$ & 0.138 & 0.272 & 0.135 & {$[0.017,0.253]$} \\
\hline $\begin{array}{l}\text { Change in Non-Interest } \\
\text { Operating Income to Assets } \\
\text { from 25th perc. to } 75 \text { th perc. } \\
\text { in } 2007\end{array}$ & 0.122 & 0.168 & 0.046 & {$[-0.000,0.0921]$} \\
\hline $\begin{array}{l}\text { Increase in Bank Size from the } \\
\text { Bottom Tercile of the Assets } \\
\text { Distribution to the Top Tercile }\end{array}$ & 0.071 & 0.372 & 0.300 & {$[0.093,0.507]$} \\
\hline $\begin{array}{l}\text { Change in Securitization } \\
\text { Underwriting from 50th perc. } \\
\text { to 90th perc. in } 2007 \text { for Small } \\
\text { Banks (in the Bottom Tercile-- } \\
\text { Assets) }\end{array}$ & 0.062 & 0.146 & 0.084 & {$[-0.028,0.196]$} \\
\hline $\begin{array}{c}\text { Change in Securitization } \\
\text { Underwriting from 50th perc. } \\
\text { to 90th perc. in } 2007 \text { for Large } \\
\text { Banks (in the Top Tercile-- } \\
\text { Assets) }\end{array}$ & 0.343 & 0.533 & 0.190 & {$[0.039,0.340]$} \\
\hline
\end{tabular}




\section{Table IX \\ Risky ABCP vehicle sponsorship and government support}

This table shows the results from estimating a probit regression in which the dependent variable is a binary indicator equal to 1 for banks that sponsored at least one SIV, securities arbitrage, or hybrid ABCP vehicle. We examine sponsorship as of June 2007. The independent variables are measured as of December of the previous year. The values in the table represent average marginal effects. Government Support is a ratings-based measure from Brandao-Marques, Correa and Sapriza (2012) that captures the bank-specific value of explicit and implicit government support; definitions for the other independent variables are found in Appendix A. Standard errors (shown in parenthesis) are clustered at the country level. *** indicates significance at the $1 \%$ level, ** indicates significance at the $5 \%$ level, and $*$ indicates significance at the $10 \%$ level.

\begin{tabular}{|c|c|c|}
\hline Dependent Variable & \multicolumn{2}{|c|}{ Sponsoring a Credit Arbitrage ABCP Vehicle=1 } \\
\hline Year & $\begin{array}{c}(1) \\
2007 \\
\end{array}$ & $\begin{array}{c}(2) \\
2007\end{array}$ \\
\hline Government Support & $\begin{array}{c}0.053^{* * *} \\
(0.016)\end{array}$ & $\begin{array}{c}0.055^{* * *} \\
(0.012)\end{array}$ \\
\hline Return on Assets & $\begin{array}{c}-0.100 \\
(0.150)\end{array}$ & $\begin{array}{l}-0.077 \\
(0.123)\end{array}$ \\
\hline Dummy Intermediate Tercile & $\begin{array}{c}0.065 \\
(0.085)\end{array}$ & $\begin{array}{c}0.093 \\
(0.068)\end{array}$ \\
\hline Dummy Top Tercile & $\begin{array}{l}0.261^{* * *} \\
(0.088)\end{array}$ & $\begin{array}{l}0.254^{* * *} \\
(0.086)\end{array}$ \\
\hline Equity to Assets & $\begin{array}{c}-0.021 \\
(0.020)\end{array}$ & $\begin{array}{l}-0.026 \\
(0.019)\end{array}$ \\
\hline Loans to Assets & $\begin{array}{l}-0.000 \\
(0.002)\end{array}$ & $\begin{array}{l}-0.001 \\
(0.003)\end{array}$ \\
\hline Deposits to Assets & $\begin{array}{c}-0.002 \\
(0.003)\end{array}$ & $\begin{array}{l}-0.001 \\
(0.003)\end{array}$ \\
\hline Non-Interest Operating Income to Assets & $\begin{array}{c}0.054^{*} \\
(0.028)\end{array}$ & $\begin{array}{c}0.043 \\
(0.031)\end{array}$ \\
\hline High Yield Underwriting & $\begin{array}{c}-0.116 \\
(0.132)\end{array}$ & $\begin{array}{l}-0.107 \\
(0.101)\end{array}$ \\
\hline Securitization Underwriting & $\begin{array}{l}0.259^{* *} \\
(0.100)\end{array}$ & $\begin{array}{l}0.247^{*} \\
(0.120)\end{array}$ \\
\hline Dummy US & $\begin{array}{l}0.222^{*} \\
(0.128)\end{array}$ & $\begin{array}{l}-0.001 \\
(0.177)\end{array}$ \\
\hline Stock Market Cap. & & $\begin{array}{c}0.000 \\
(0.001)\end{array}$ \\
\hline Private Bond Market Cap. & & $\begin{array}{l}0.003^{*} \\
(0.001)\end{array}$ \\
\hline Real GDP Growth & & $\begin{array}{l}-0.091^{*} \\
(0.054)\end{array}$ \\
\hline Observations & 91 & 91 \\
\hline Countries & 16 & 16 \\
\hline Pseudo R2 & 0.325 & 0.361 \\
\hline
\end{tabular}




\section{Table X \\ Robustness checks}

This table shows the results from estimating a probit regression in which the dependent variable is a binary indicator equal to 1 for banks that sponsored at least one SIV, securities arbitrage, or hybrid ABCP vehicle. In this table, we examine sponsorship at mid-2007. The independent variables are measured as of December of the previous year. The values in the table represent average marginal effects. Definitions for the independent variables are found in Appendix A. Columns 1 and 2 exclude German Landesbanks from the sample, Columns 3 and 4 exclude U.S. banks from the sample, and Columns 5 and 6 exclude both U.S. banks and German Landesbanks. Standard errors (shown in parenthesis) are clustered at the country level. *** indicates significance at the $1 \%$ level, ** indicates significance at the $5 \%$ level, and * indicates significance at the $10 \%$ level.

\begin{tabular}{|c|c|c|c|c|c|c|}
\hline \multirow{3}{*}{$\begin{array}{l}\text { Dependent Variable } \\
\text { Sample }\end{array}$} & \multicolumn{6}{|c|}{ Sponsoring a Credit Arbitrage ABCP Vehicle=1 } \\
\hline & \multicolumn{2}{|c|}{$\begin{array}{l}\text { All banks excluding } \\
\text { Landesbanks }\end{array}$} & \multicolumn{2}{|c|}{ European banks } & \multicolumn{2}{|c|}{$\begin{array}{l}\text { European banks } \\
\text { excluding Landesbanks }\end{array}$} \\
\hline & (1) & (2) & (3) & (4) & $(5)$ & (6) \\
\hline Return on Assets & $\begin{array}{l}-0.041 \\
(0.086)\end{array}$ & $\begin{array}{c}-0.033 \\
(0.083)\end{array}$ & $\begin{array}{c}-0.275^{* *} \\
(0.094)\end{array}$ & $\begin{array}{l}-0.216^{* *} \\
(0.095)\end{array}$ & $\begin{array}{l}-0.283^{* *} \\
(0.108)\end{array}$ & $\begin{array}{l}-0.240^{*} \\
(0.118)\end{array}$ \\
\hline Dummy Intermediate Tercile & $\begin{array}{c}0.020 \\
(0.063)\end{array}$ & $\begin{array}{c}0.036 \\
(0.059)\end{array}$ & $\begin{array}{c}0.049 \\
(0.100)\end{array}$ & $\begin{array}{c}0.034 \\
(0.096)\end{array}$ & $\begin{array}{c}0.001 \\
(0.101)\end{array}$ & $\begin{array}{l}-0.010 \\
(0.101)\end{array}$ \\
\hline Dummy Top Tercile & $\begin{array}{l}0.211^{* *} \\
(0.089)\end{array}$ & $\begin{array}{l}0.224^{* * *} \\
(0.086)\end{array}$ & $\begin{array}{l}0.322^{* * * *} \\
(0.068)\end{array}$ & $\begin{array}{l}0.305^{* * *} \\
(0.074)\end{array}$ & $\begin{array}{l}0.296^{* * *} \\
(0.070)\end{array}$ & $\begin{array}{l}0.286^{* * *} \\
(0.080)\end{array}$ \\
\hline Equity to Assets & $\begin{array}{l}-0.020^{* *} \\
(0.008)\end{array}$ & $\begin{array}{c}-0.030^{* * *} \\
(0.007)\end{array}$ & $\begin{array}{l}-0.022 \\
(0.019)\end{array}$ & $\begin{array}{l}-0.034^{*} \\
(0.016)\end{array}$ & $\begin{array}{l}-0.016 \\
(0.016)\end{array}$ & $\begin{array}{l}-0.025 \\
(0.013)\end{array}$ \\
\hline Loans to Assets & $\begin{array}{l}-0.000 \\
(0.003)\end{array}$ & $\begin{array}{l}-0.000 \\
(0.003)\end{array}$ & $\begin{array}{c}0.001 \\
(0.002)\end{array}$ & $\begin{array}{c}0.001 \\
(0.002)\end{array}$ & $\begin{array}{l}0.003^{* *} \\
(0.002)\end{array}$ & $\begin{array}{c}0.003 \\
(0.002)\end{array}$ \\
\hline Deposits to Assets & $\begin{array}{c}0.001 \\
(0.001)\end{array}$ & $\begin{array}{c}0.000 \\
(0.001)\end{array}$ & $\begin{array}{c}0.001 \\
(0.001)\end{array}$ & $\begin{array}{c}0.002^{*} \\
(0.001)\end{array}$ & $\begin{array}{l}-0.001 \\
(0.001)\end{array}$ & $\begin{array}{c}0.000 \\
(0.001)\end{array}$ \\
\hline $\begin{array}{l}\text { Non-Interest Operating } \\
\text { Income to Assets }\end{array}$ & $\begin{array}{l}0.058^{*} \\
(0.032)\end{array}$ & $\begin{array}{c}0.041 \\
(0.030)\end{array}$ & $\begin{array}{c}0.012 \\
(0.038)\end{array}$ & $\begin{array}{l}-0.020 \\
(0.041)\end{array}$ & $\begin{array}{c}0.069^{*} \\
(0.031)\end{array}$ & $\begin{array}{c}0.040 \\
(0.040)\end{array}$ \\
\hline High Yield Underwriting & $\begin{array}{c}0.031 \\
(0.144)\end{array}$ & $\begin{array}{l}-0.003 \\
(0.122)\end{array}$ & $\begin{array}{l}-0.097 \\
(0.171)\end{array}$ & $\begin{array}{l}-0.076 \\
(0.189)\end{array}$ & $\begin{array}{l}-0.060 \\
(0.144)\end{array}$ & $\begin{array}{l}-0.050 \\
(0.156)\end{array}$ \\
\hline Securitization Underwriting & $\begin{array}{c}0.183^{* * *} \\
(0.050)\end{array}$ & $\begin{array}{l}0.144^{* *} \\
(0.047)\end{array}$ & $\begin{array}{l}0.150^{* *} \\
(0.057)\end{array}$ & $\begin{array}{c}0.126^{*} \\
(0.065)\end{array}$ & $\begin{array}{c}0.138^{* * *} \\
(0.048)\end{array}$ & $\begin{array}{l}0.111^{*} \\
(0.058)\end{array}$ \\
\hline Stock Market Cap. & & $\begin{array}{c}0.000 \\
(0.001)\end{array}$ & & $\begin{array}{c}0.000 \\
(0.001)\end{array}$ & & $\begin{array}{c}0.000 \\
(0.001)\end{array}$ \\
\hline Private Bond Market Cap. & & $\begin{array}{l}0.002^{* *} \\
(0.001)\end{array}$ & & $\begin{array}{c}0.001 \\
(0.002)\end{array}$ & & $\begin{array}{c}0.001 \\
(0.002)\end{array}$ \\
\hline Real GDP Growth & & $\begin{array}{l}-0.052 \\
(0.050)\end{array}$ & & $\begin{array}{l}-0.071 \\
(0.058)\end{array}$ & & $\begin{array}{l}-0.061 \\
(0.055)\end{array}$ \\
\hline Observations & 136 & 135 & 112 & 111 & 103 & 102 \\
\hline Countries & 18 & 17 & 17 & 16 & 17 & 16 \\
\hline Pseudo $\mathrm{R}^{2}$ & 0.294 & 0.322 & 0.342 & 0.358 & 0.361 & 0.380 \\
\hline
\end{tabular}




\section{Table XI \\ Risky ABCP vehicle sponsorship and agency problems}

This table shows the results from estimating a probit regression in which the dependent variable is a binary indicator equal to 1 for banks that sponsored at least one SIV, securities arbitrage, or hybrid vehicle as of mid-2007. The independent variables are measured as of December of the previous year. The values in the table represent average marginal effects. Higher values of Compensation Index represent better firm-level compensation practices as defined by RiskMetrics Corporate Governance Quotient. Insider ownership is the percentage stake held by individual insiders. Board Independence is the share of independent directors on the bank's board of directors, Institutional Ownership is the percent of shares owned by institutions, and Widely Held is a dummy variable equal to 1 if the bank does not have a single owner with voting shares larger than $10 \%$. Definitions for the remaining independent variables are found in Appendix A. While not shown to conserve space, these estimations include the same country-level control variables used in column 2 of Table VII. Note that with the exception of column (5), this estimation sample does not include Landesbanks. Standard errors (shown in parenthesis) are clustered at the country level. *** indicates significance at the $1 \%$ level, ** indicates significance at the $5 \%$ level, and * indicates significance at the $10 \%$ level.

\begin{tabular}{|c|c|c|c|c|c|c|}
\hline \multirow[t]{2}{*}{ Dependent Variable } & \multicolumn{6}{|c|}{ Sponsoring a Credit Arbitrage ABCP Vehicle $=1$} \\
\hline & $(1)$ & $(2)$ & (3) & $(4)$ & $(5)$ & $(6)$ \\
\hline Compensation Index & $\begin{array}{c}-0.005^{* * *} \\
(0.002)\end{array}$ & & & & & $\begin{array}{c}-0.004^{* * *} \\
(0.001)\end{array}$ \\
\hline Insider Ownership & & $\begin{array}{c}0.107 \\
(0.510)\end{array}$ & & & & $\begin{array}{c}0.125 \\
(0.793)\end{array}$ \\
\hline Board Independence & & & $\begin{array}{l}-0.195 \\
(0.126)\end{array}$ & & & $\begin{array}{l}-0.049 \\
(0.179)\end{array}$ \\
\hline Institutional Ownership & & & & $\begin{array}{l}0.453^{* *} \\
(0.182)\end{array}$ & & $\begin{array}{c}0.263 \\
(0.199)\end{array}$ \\
\hline Widely Held & & & & & $\begin{array}{l}0.126^{* *} \\
(0.060)\end{array}$ & $\begin{array}{c}0.101^{*} \\
(0.053)\end{array}$ \\
\hline Return on Assets & $\begin{array}{c}0.089 \\
(0.085)\end{array}$ & $\begin{array}{l}0.170^{*} \\
(0.078)\end{array}$ & $\begin{array}{c}0.044 \\
(0.060)\end{array}$ & $\begin{array}{c}0.158 \\
(0.093)\end{array}$ & $\begin{array}{l}-0.040 \\
(0.074)\end{array}$ & $\begin{array}{c}0.118 \\
(0.111)\end{array}$ \\
\hline Dummy Intermediate Tercile & $\begin{array}{c}0.005 \\
(0.063)\end{array}$ & $\begin{array}{l}0.073^{*} \\
(0.040)\end{array}$ & $\begin{array}{c}0.089 \\
(0.089)\end{array}$ & $\begin{array}{c}0.071 \\
(0.065)\end{array}$ & $\begin{array}{c}0.053 \\
(0.048)\end{array}$ & $\begin{array}{c}0.082 \\
(0.076)\end{array}$ \\
\hline Dummy Top Tercile & $\begin{array}{c}0.214^{*} \\
(0.117)\end{array}$ & $\begin{array}{l}0.207^{*} \\
(0.110)\end{array}$ & $\begin{array}{l}0.231^{*} \\
(0.144)\end{array}$ & $\begin{array}{c}0.138 \\
(0.105)\end{array}$ & $\begin{array}{c}0.240^{* * *} \\
(0.086)\end{array}$ & $\begin{array}{c}0.146 \\
(0.115)\end{array}$ \\
\hline Equity to Assets & $\begin{array}{c}-0.033^{* * *} \\
(0.012)\end{array}$ & $\begin{array}{l}-0.029^{* * *} \\
(0.012)\end{array}$ & $\begin{array}{l}-0.037^{* *} \\
(0.018)\end{array}$ & $\begin{array}{c}-0.028^{* *} \\
(0.011)\end{array}$ & $\begin{array}{c}-0.037^{* * *} \\
(0.014)\end{array}$ & $\begin{array}{l}-0.022^{*} \\
(0.011)\end{array}$ \\
\hline Loans to Assets & $\begin{array}{c}-0.006^{* *} \\
(0.002)\end{array}$ & $\begin{array}{l}-0.007^{* *} \\
(0.003)\end{array}$ & $\begin{array}{l}-0.004 \\
(0.003)\end{array}$ & $\begin{array}{l}-0.007^{* *} \\
(0.002)\end{array}$ & $\begin{array}{l}-0.003 \\
(0.003)\end{array}$ & $\begin{array}{c}-0.007^{* * *} \\
(0.002)\end{array}$ \\
\hline Deposits to Assets & $\begin{array}{l}-0.004 \\
(0.002)\end{array}$ & $\begin{array}{l}-0.002 \\
(0.003)\end{array}$ & $\begin{array}{l}-0.000 \\
(0.002)\end{array}$ & $\begin{array}{l}-0.002 \\
(0.003)\end{array}$ & $\begin{array}{c}0.001 \\
(0.001)\end{array}$ & $\begin{array}{l}-0.002 \\
(0.003)\end{array}$ \\
\hline Non-Interest Operating Income to Assets & $\begin{array}{l}-0.001 \\
(0.041)\end{array}$ & $\begin{array}{l}-0.069 \\
(0.058)\end{array}$ & $\begin{array}{c}0.007 \\
(0.039)\end{array}$ & $\begin{array}{l}-0.078 \\
(0.064)\end{array}$ & $\begin{array}{c}0.007 \\
(0.018)\end{array}$ & $\begin{array}{l}-0.063 \\
(0.070)\end{array}$ \\
\hline High Yield Underwriting & $\begin{array}{l}-0.100 \\
(0.146)\end{array}$ & $\begin{array}{c}0.210 \\
(0.199)\end{array}$ & $\begin{array}{l}-0.030 \\
(0.130)\end{array}$ & $\begin{array}{c}0.037 \\
(0.142)\end{array}$ & $\begin{array}{l}-0.059 \\
(0.138)\end{array}$ & $\begin{array}{c}0.254 \\
(0.231)\end{array}$ \\
\hline Securitization Underwriting & $\begin{array}{c}0.103 \\
(0.100)\end{array}$ & $\begin{array}{c}0.019 \\
(0.073)\end{array}$ & $\begin{array}{c}0.118 \\
(0.071)\end{array}$ & $\begin{array}{l}0.125^{*} \\
(0.066)\end{array}$ & $\begin{array}{c}0.132^{*} \\
(0.073)\end{array}$ & $\begin{array}{c}0.023 \\
(0.130)\end{array}$ \\
\hline Dummy US & $\begin{array}{c}0.345 \\
(0.221)\end{array}$ & $\begin{array}{c}0.075 \\
(0.197)\end{array}$ & $\begin{array}{c}0.164 \\
(0.167)\end{array}$ & $\begin{array}{l}-0.115 \\
(0.174)\end{array}$ & $\begin{array}{c}0.041 \\
(0.194)\end{array}$ & $\begin{array}{c}0.023 \\
(0.189)\end{array}$ \\
\hline Observations & 89 & 84 & 96 & 85 & 144 & 74 \\
\hline Countries & 17 & 17 & 17 & 17 & 17 & 17 \\
\hline Pseudo $\mathrm{R}^{2}$ & 0.424 & 0.407 & 0.327 & 0.425 & 0.329 & 0.450 \\
\hline
\end{tabular}

